CEP Discussion Paper No 757

October 2006

\title{
Unemployment and Hours of Work: The North Atlantic Divide Revisited
}

Christopher Pissarides 


\begin{abstract}
I examine the dynamic evolutions of unemployment, hours of work and the service share since the war in the United States and Europe. The theoretical model brings together all three and emphasizes technological growth. Computations show that the very low unemployment in Europe in the 1960s was due to the high productivity growth associated with technological catch-up. Productivity also played a role in the dynamics of hours but a full explanation for the fast rise of service employment and the big fall in aggregate hours needs further research. Taxation has played a role but results are mixed.
\end{abstract}

\title{
Acknowledgements
}

I am especially grateful to Rachel Ngai for her help with the model of structural change, which is derived from our joint work (Ngai-Pissarides, 2005). I am also grateful to Barbara Petrongolo and Richard Rogerson for comments and to Evangelia Vourvachaki and Katrin Tinn for research assistance. Financial assistance from the ESRC (project no. RES-000-22-0917) is gratefully acknowledged. This paper was delivered as The Lawrence Klein Lecture, presented at the University of Pennsylvania on 12 April 2006.

Christopher Pissarides is Director of the Macro Programme at the Centre for Economic Performance and Professor of Economics and Norman Sosnow Chair in Economics at the London School of Economics.

JEL: E24, J21, J22, J64, O14

Keywords: Unemployment, hours of work, service employment, structural change, labor productivity taxation

Published by

Centre for Economic Performance

London School of Economics and Political Science

Houghton Street

London WC2A 2AE

All rights reserved. No part of this publication may be reproduced, stored in a retrieval system or transmitted in any form or by any means without the prior permission in writing of the publisher nor be issued to the public or circulated in any form other than that in which it is published.

Requests for permission to reproduce any article or part of the Working Paper should be sent to the editor at the above address.

(C) Christopher Pissarides, submitted August 2006

ISBN 0753020637 


\section{Introduction}

Three features characterize the dynamics of European labor markets in the post-war era. Unemployment has increased substantially, both absolutely and relative to US unemployment; overall hours of work have fallen, both absolutely and relative to US hours; hours of work in service employment have risen, but the service sector is still smaller than it is in the United States.

One or more of these features are often cited as evidence that European labor markets have underperformed in the post-war era. Are these features interconnected and are they symptoms of under-performance? Answers to these questions require a model and this is the challenge that I take up in this paper. I develop a simple model that can be used to study simultaneously the three facts cited in my opening paragraph. Although the emphasis of my paper is on the theoretical framework, I show with OECD data where the main differences between the major European countries and the United States are, and what is needed for a full empirical analysis. The dynamics of European unemployment have been studied extensively but there is no consensus about the causes of the large swings observed in the post-war era. Rigid institutions, high taxation and a generous welfare state in Europe seem to have played a part, but negative world-wide shocks also contributed to the rise in unemployment.1 I emphasize here a factor that although not entirely neglected in the recent literature, its full importance for unemployment has not been appreciated: productivity growth.

Economists were aware of the role of productivity growth at a time when Americans looked at the European record with envy. Speaking in 1963, Robert Myers, then Deputy Commissioner of the Bureau of Labor Statistics, claimed, "Unemployment has been a much less serious problem in the industrial countries of Europe in recent years than here, but the lessons we can learn from their experience - and put to practical application - are distinctly limited" (Myers 1964 p. 185). Ironically, it was thought that the European institutions that were blamed for the rise in unemployment twenty years later shielded European countries from macroeconomic shocks. They were unattainable in the United States because "of the American belief in the desirability of market solutions".2 But a main conclusion of both Myers

1 For a sample of works on unemployment and the role of institutions see Bruno and Sachs (1985), Layard, Nickell and Jackman (1991), Phelps (1994), Nickell (1997), Gordon (1997), Mortensen and Pissarides (1999), Blanchard and Wolfers (2000), Nickell, Nunziata and Ochel (2005) and Blanchard (2006).

2This last quotation is not from Myers (1964) but from Downie (1964, p.161), who expressed similar views to those of Myers', with some more comments into the political economy of labor market policy. 
and relative to US unemployment; overall hours of work have fallen, both absolutely and relative to US hours; hours of work in service employment have risen, but the service sector is still smaller than it is in the United States.

One or more of these features are often cited as evidence that European labor markets have underperformed in the post-war era. Are these features interconnected and are they symptoms of under-performance? Answers to these questions require a model and this is the challenge that I take up in this paper. I develop a simple model that can be used to study simultaneously the three facts cited in my opening paragraph. Although the emphasis of my paper is on the theoretical framework, I show with OECD data where the main differences between the major European countries and the United States are, and what is needed for a full empirical analysis.

The dynamics of European unemployment have been studied extensively but there is no consensus about the causes of the large swings observed in the post-war era. Rigid institutions, high taxation and a generous welfare state in Europe seem to have played a part, but negative world-wide shocks also contributed to the rise in unemployment. ${ }^{1}$ I emphasize here a factor that although not entirely neglected in the recent literature, its full importance for unemployment has not been appreciated: productivity growth.

Economists were aware of the role of productivity growth at a time when Americans looked at the European record with envy. Speaking in 1963, Robert Myers, then Deputy Commissioner of the Bureau of Labor Statistics, claimed, "Unemployment has been a much less serious problem in the industrial countries of Europe in recent years than here, but the lessons we can learn from their experience - and put to practical application - are distinctly limited" (Myers 1964 p. 185). Ironically, it was thought that the European institutions that were blamed for the rise in unemployment twenty years later shielded European countries from macroeconomic shocks. They were unattainable in the United States because "of the American belief in the desirability of market solutions". ${ }^{2}$ But a main conclusion of both Myers

\footnotetext{
${ }^{1}$ For a sample of works on unemployment and the role of institutions see Bruno and Sachs (1985), Layard, Nickell and Jackman (1991), Phelps (1994), Nickell (1997), Gordon (1997), Mortensen and Pissarides (1999), Blanchard and Wolfers (2000), Nickell, Nunziata and Ochel (2005) and Blanchard (2006).

${ }^{2}$ This last quotation is not from Myers (1964) but from Downie (1964, p.161), who expressed similar views to those of Myers', with some more comments into the political economy of labor market policy.
} 
and Downie was that a key reason for the lower unemployment in Europe was its faster economic growth, which was unattainable in the United States because it was the result of a "gradual recovery from a devastating war and the delayed attainment of industrial maturity" (Myers, 1964, p. 184). I will show here that there is some credence to this view. One of the reasons that we refer to a "European unemployment problem" is that we are comparing an exceptional period, the period up to the early 1970s, with one that is closer to a steady state, the 1990s.

The long-run dynamics of overall hours of work have been studied much less than the dynamics of unemployment. The dynamics of structural change and their interaction with unemployment and overall hours of work have been studied even less in the recent literature. Two recent exceptions to this that are closely related to the argument of this paper are Rogerson $(2004,2006)$ and Freeman and Schettkat (2005). In both papers the authors emphasize substitutions between home production and market work, as we do here. Rogerson (2004) studied the role of technology and taxation in the evolution of hours of work in postwar Europe and America, and found that although technological catch-up can explain some of the different experiences observed, higher taxation in Europe also contributes to the explanation. Freeman and Schettkat (2005) also looked at overall hours of work but also at hours in sectors that have close substitutes in the home, such as restaurants and child care. They found more home work being done in Europe, especially by women, which can explain some of the cross-country differences in hours of work. ${ }^{3}$ In this paper I will show how substitutions between home and market production are influenced by unemployment and other factors. By looking at the data I will be able to say something about the source of the main differences in cross-country performance. But I will show that neither productivity growth nor taxation can explain simultaneously the evolution of European hours of work and the share of services.

A contribution of this paper is the development of a tractable model with endogenous variables the rate of unemployment, overall hours of work and the distribution of hours between different sectors, in particular services and other sectors. The exogenous variables are technology and policy. The derivation of explicit analytical solutions depends on two key assumptions. The first is that there are two parallel markets, one for labor and the other for

\footnotetext{
${ }^{3}$ See Ngai and Pissarides (2005) for a dynamics model of hours allocations consistent with the results of these papers.
} 
final goods, that function virtually independently from each other. The objective of agents participating in the labor market is to maximize income, for a given allocation of total working time (the participation rate). The equilibrium outcomes from this market are total income and the allocation of time to employment in different sectors and to unemployment. In the goods market a representative agent maximizes a utility function defined over consumption goods and leisure, subject to the per capita income generated in the labor market. The equilibrium outcomes are the demand functions for goods and the allocation of the time endowment to the home (leisure and home production) and the market. So there is a two-way interaction between the two markets, the labor market creating the income that constraints consumption choices and the goods market giving the allocation of time that constraints employment in the labor market. Given these constraints, each market reaches equilibrium independently from the other. ${ }^{4}$

The second assumption is that each market reaches steady-state equilibrium within a single 'period'. The model is specified in continuous time so 'period' refers to the transition from the model to the data. Partly because of data limitations, we can think of a year as the period. During the year the labor market reaches the conventional steady-state equilibrium of search theory, and the goods market is in an equilibrium derived from a static maximization problem. There is no capital in the model so the only state variables are the exogenous labor productivity parameters. For a given set of parameters the goods market gives demand functions for consumption goods and leisure, and the labor market gives total employment and unemployment. When in the following year the productivity parameters change, there is a new set of demand functions and employment-unemployment decomposition, also derived from a steady state with the new set of parameters. This period-by-period progression describes the dynamics of the model in real time.

The justification for this assumption is that the search frictions are not large enough to keep the economy off its steady-state path for long. Intuitively, being in the steady state of search theory is equivalent to being on the Beveridge curve, as opposed to looping around it. The dynamics of un-

\footnotetext{
${ }^{4}$ This assumption is the adaptation to our environment of an assumption normally used in business cycle models with search in the labor market. The usual justification is that there is insurance, either provided by a market not modeled or by large family units, that allocates the total income created in the labor market equally across all market participants (see Andolfatto 1996, Merz 1995 and Den Haan, Ramey and Watson 2000).
} 
employment in this case are driven by changes in the transition rates and not by the internal dynamics of unemployment for given rates. I showed in Pissarides (1986) that the evolution of British unemployment can be accurately traced by the assumption that the labor market is on the Beveridge curve at all times. I also showed that the transition rate that drives the evolution is the one from unemployment to employment, with the transition rate from employment to unemployment held constant. Similar conclusions were reached by Shimer (2005) and Hall (2006) for the United States. The assumption that the allocation of income to goods and leisure is obtained from a static problem follows trivially from the assumption that the labor market is in equilibrium and there is no capital in the model.

Section 2 describes the main relevant facts for the United States and the main European economies. Section 3 discusses the assumptions made about market structure and sections 4 and 5 respectively derive the labor-market equilibrium conditions and the goods-market equilibrium conditions. Section 6 completes the description of equilibrium by bringing together the results of the previous two sections. Sections 7 and 8 discuss the results of calibrations with the model and section 9 introduces taxation and discusses both the theory behind it and its quantitative implications.

\section{Data}

I focus on six countries, the United States, the four big European countries and Sweden. Any talk of Europe and underperformance has to include the big three continental economies. I include Britain because up to about 1990 its labor market performance was very similar to that of the three continental economies, but moved closer to the United States thereafter. Finally, I include Sweden because it is the biggest of the Scandinavian countries, which followed a different, more interventionist, model and apparently did a lot better than the continental European countries. Another feature of Sweden that is useful in my argument is that its economy was not destroyed by war, and followed a different convergence path. In the 1960s it was the richest European country, by 2000 its per capita income was below that of the major European economies.

A striking difference in the dynamics of US and European labor markets is in hourly productivity. Figure 1 shows the trends in the six countries of the sample. In 1950 European economies emerged destroyed after the war, 
with little and over-used capital stock and low labor productivity. There followed a period of rapid growth and eventual convergence with the United States, some 25-30 years later. The United States had the lowest productivity growth rate in the post-war era, up to the mid 1980s. Britain was the other country with low productivity growth. But by the late 1980s all countries more or less converged.

I next show in three figures the smoothed series for the three variables that are my focus here, unemployment, annual hours of work in terms of the population of working age, and the annual hours of work in services in the population of working age. Unemployment is defined in the usual OECD way, as a percentage of the labor force. The hours series is simply annual hours of work divided by the population aged 15-64. For services I first constructed the employment share of services, in persons, which is the only series available for all the countries. I then multiplied this by total annual hours of work and divided by the population of working age.

Looking first at the unemployment series, shown in figure 2, experience is diverse. The striking feature of the overall picture since 1950, however, is that the European countries have experienced bigger fluctuations in their unemployment series than did the United States. Viewed from a longer-run perspective, the main difference between European and American unemployment is in the variance, not in the level. Whether this is a fact that will persist remains to be seen, as more data come online. But if it is a fact it is a puzzling one. The institutions that are supposed to have worsened European outcomes are supposed to reduce the fluctuations in unemployment, not increase them. For example, employment protection and unions both encourage labor hoarding in recessions.

European countries up to the early 1970s, with the exception of Italy, had historically low unemployment rates of 2 percent or below. Following this era unemployment went up everywhere, in the four big economies of Europe by the same order of magnitude, in the United States by less and in Sweden with a long delay. The delay in Sweden was caused by expansionary macro policy and devaluations, which had to be abandoned when the country entered the European Monetary Union (although not the single currency). The notable exception in the more recent dynamics of European unemployment is the fast decline in British unemployment, which has not yet been matched by the other countries. But unemployment has been falling everywhere.

The dynamics of total hours of work are more in line with the traditional consensus on the US-EU comparison (see figure 3). Whereas hours of work 
have fallen everywhere in Europe, the fall was biggest in the three continental countries. The United States is an exception in this respect, in that hours of work have risen. The rise was due to the rise in female participation, a trend that started in Europe as well, but with a delay. So whereas the United States had the lowest number of annual hours in 1960, by 2000 it far exceeded all the other countries in the sample. And whereas Germany had the largest number of hours of work in 1960, by 2000 it had, with France, the lowest. The fall in hours of work in Europe is attributed mainly to the fall in mean hours for the working population. Employment rates for younger and older workers also fell but employment rates for women rose to partially offset them, in contrast to the United States which experienced a rapid rise in overall employment - a feature sometimes referred to in Europe as the "American employment miracle."

The dynamics of service employment only partly reflect the dynamics of overall hours (figure 4). The United States had more employment in services throughout the period, and perhaps not surprisingly, given the dynamics of overall hours, the gap widened during the sample period. France and Germany had virtually identical experiences with service employment, with Italy catching up with them in the latter part of the sample. Britain and Sweden had very similar experiences with each other too. But interestingly, the gap in hours of work in service employment between the United States and the European economies is always bigger than the overall gap - which indicates that the European economies put more hours into manufacturing and agriculture than did the United States.

Two more types of data are useful in the analysis that follows. First, how is non-working time allocated between home production and leisure, and second, what relation is there between work time and unemployment? For the first, I use mainly time-use data reported in Freeman and Schettkat (2005) to show a US-European comparison. They use time-use survey results for seven European countries and the United States, including all the countries in our sample except for France, to study time allocations in the age group 25-54 years. They concluded that the main reason for cross-country differences in market work are differences in home production. See Table 1. Crosscountry differences in their sample are driven by female allocations, as the men have very similar cross-country patterns. ${ }^{5}$ Further work on substitutions

\footnotetext{
${ }^{5}$ Italy is an outlier in men's allocations, reporting very low home work time and correspondingly high personal care and leisure time. This explains the differences in the results
} 
over time led the authors to conclude that there are significant substitutions between all the three uses of time - market work, home work and leisure. But significantly, for women the main substitutions are between home work and market work. For men the substitution elasticities between market work and each of the other two uses of time are about the same. Translated to aggregate time patterns this finding is saying that the changes in market work accounted for by women are matched mainly by changes in home production time, whereas the changes accounted for by men are matched about equally by changes in home work and in leisure. ${ }^{6}$

We conclude that the fall in European hours of work, which is mainly the result of the fall in male hours, is reflected in a rise in both home production time and leisure time. But the rise in female participation, which was stronger in the United States than elsewhere, is reflected mainly in a fall in home production time. For the United States in particular, where there are better quality data on time use, Aguiar and Hurst (2005) concluded that there has been a small rise in leisure since the 1960s, accounted for mainly by the fall in home production time. Their results are consistent with the results of Ramey and Francis (2005), who used a different population base to conclude that on average leisure time has remained more or less constant for much of the 20 th century, with a small rise in more recent decades. ${ }^{7}$

A final fact that I look at is the correlation between the participation rate and the unemployment rate. I remove high frequency fluctuations from the data as over the business cycle such a correlation would be due to factors that I do not examine here. Figure 5 shows the cross-section correlation between the two series in 19 OECD countries. There is some, although not strong negative correlation. Participation in the figure is measured by the number of people either employed or unemployed in the population of working age. If we convert to hours of participation instead, (constructed by dividing annual hours of work by $1-u$, where $u$ is the unemployment rate) the correlation

for men in the Table.

${ }^{6}$ The caveat should be expressed that the Freeman-Schettkat sample is restricted to ages 25-54. Most of the fall in participation for both men and women, but mainly for men, is accounted for by the age groups $15-24$ and $55-65$, so generalizations may not be accurate.

${ }^{7}$ Greenwood, Seshadri and Yorukoglu (2005) claimed that the rise in female participation was driven by technological advances in the home, which freed women's time. Ngai and Pissarides (2005) also explain the rise in hours of work in the United States by technology, but through a different channel, improvements in the market-production technology which outstripped the home-production technology. 
Table 1: Time use, persons aged 25-54, weekly hours

\begin{tabular}{lccccc}
\hline \hline & Market work & Home work & Total work & Leisure & Personal care \\
\hline US 1992 & & & & & \\
Men & 44.1 & 16.1 & 60.2 & 36.4 & 70.7 \\
Women & 28.7 & 30.1 & 58.8 & 35.0 & 71.2 \\
Europe 1990s & & & & & \\
Men & 43.4 & 13.6 & 56.9 & 37.4 & 73.6 \\
Women & 20.7 & 40.5 & 61.2 & 32.1 & 74.6 \\
\hline Nom
\end{tabular}

Notes. Source: Freeman and Schettkat (2005), Table 3.

is less good.

\section{Description of the economy}

Production takes place in three separate sectors. Two of these sectors are located in the market and production takes place after a match between the firm and the worker. The third sector is located in the home and the household allocates time to it to produce without involving a firm. The main feature that distinguishes the market sectors from each other is that the output of one is a better substitute for the home-produced good than is the output of the other. I refer to the sector that produces the better substitute as the service sector, and to the other sector as manufacturing. ${ }^{8}$

Production in all sectors takes place according to a constant returns production function that employs only labor, so service output is $A_{s} N_{s}$ and manufacturing output $A_{m} N_{m}$, where $A_{i}$ generally denotes technology and $N_{i}$ employment. Home-produced output is given by $A_{h} N_{h}$. The rate of growth of $A_{i}$ is denoted $\gamma_{i}$ and the vector of $A_{i}$ and $\gamma_{i}(i=s, m, h)$ describes the state of the economy. In the countries in our sample $\gamma_{m} \geq \gamma_{s} \geq \gamma_{h}$, but the description of equilibrium does not require any quantitative restrictions on the $\gamma_{i}$.

There are frictions when moving from the home to the market and when changing jobs in the market, but these do not delay matching sufficiently to

\footnotetext{
${ }^{8}$ Given the difficulties of distinguishing between good and poor substitutes for home production in the data, in the quantitative analysis I match the good substitutes with the entire service sector and the poor substitutes with the rest of the economy. This is not to deny that there are services that do not have good substitutes in the home and there are activities outside services that have good substitutes.
} 
cause substantial deviations of marginal products. I assume that sectorial labor allocations ensure that the value of marginal product of labor in each sector is common. I use some arbitrary weighted average of the prices of the two market goods as numeraire, and let $p_{m}$ and $p_{s}$ denote the prices of manufacturing and service goods respectively, in terms of the numeraire. The value of marginal product in manufacturing is $p_{m} A_{m}$ and in services $p_{s} A_{s}$, so equality of marginal products implies, $p_{s} / p_{m}=A_{m} / A_{s}$. I define $A \equiv p_{m} A_{m}=$ $p_{s} A_{s}$ and refer to it as labor productivity (or simply as productivity). In equilibrium both workers and firms are indifferent which sector they enter, so we can model the allocation of time to employment and unemployment in a representative sector with productivity parameter $A$ and rate of growth $\gamma \equiv \gamma_{m}+\dot{p}_{m} / p_{m}=\gamma_{s}+\dot{p}_{s} / p_{s}$. Both $A$ and $\gamma$ are in terms of the numeraire.

Decisions take place as follows. In the labor market there is a given allocation of time $L$ and a known $A$ and $\gamma$, which describe its state. Workers and firms maximize income over an infinite horizon and the outcome is a division of $L$ between employment $N$ and unemployment $L-N$, a post-tax wage $(1-\tau) w$ for each employed worker and a net transfer for each unemployed worker $b=\rho(1-\tau) w$. Here $\tau$ and $\rho$ (the replacement rate) are numbers between zero and one and exogenous policy instruments. Taxes are used to finance unemployment compensation and other government expenditure. In the benchmark model I assume that the only expenditure is unemployment compensation and the budget is balanced, and let $\tau_{b}$ denote the tax rate. The total net income generated in the benchmark labor market by worker decisions is $w N$, and is distributed between employed and unemployed workers according to the compensation parameter $b$. Employment allocations are then divided to satisfy $N_{m}+N_{s}=N$ and the demand functions for goods derived in the goods market.

In the goods market, a representative agent chooses consumption levels for the three goods, $c_{i}(i=s, m, h)$, and home time $1-L-N_{h}$ and $N_{h}$, to maximize a utility function given $w, b, p_{m}, p_{s}$ and the production function for home services, $c_{h}=A_{h} N_{h}$. This maximization gives the $L$ that describes the state in the labor market, and the consumption demands that determine the allocation of employment to manufacturing and services. 


\section{Unemployment and wages}

The labor market is modeled as in the simplest model with growth in Pissarides (2000, chapter 3$)$ with constant rate of job separation and matching frictions derived from an aggregate matching function. The intensity of search is constant, but I will argue later in this section that the introduction of variable intensity enhances the impact of productivity growth on employment.

The separation rate for existing jobs is denoted by $\lambda$ and is a constant. Let the matching function be

$$
m=(s u)^{\eta} v^{1-\eta}, \quad \eta \in(0,1)
$$

where $s$ is a constant and $u$ and $v$ are respectively the unemployment and vacancy rates. $s$ could stand for the efficiency of matching or for the intensity of each unemployed worker's search, an issue which I discuss later on. I define the transition rate of the typical unemployed worker by $p=m / u=s^{\eta} \theta^{1-\eta}$, where $\theta$ is the tightness measure, $\theta \equiv v / u$, and the transition of the typical vacancy by $q=m / v=s^{\eta} \theta^{-\eta}$. The objective in this section is to derive an equation for $\theta$ for a fixed $s$ and show that it gives a unique solution for employment and wages conditional on $L$.

The equation for $\theta$ is derived from the choices made by firms. Let $V$ denote the value of a vacancy and $J$ the value of an occupied job. The Bellman equations giving their values are,

$$
\begin{aligned}
r V & =-\kappa A+q(J-V)+\dot{V}, \\
r J & =A-w-\lambda J+\dot{J} .
\end{aligned}
$$

The cost of holding a vacancy is a multiple $\kappa$ of the product per worker. The firm buys recruitment services from other firms that are already matched. Although it is more plausible to assume that recruitment services are the output of the service sector, it is analytically more convenient to assume that each sector buys recruitment services from other firms in its sector. Our results do not depend on this assumption.

The wage rate is assumed to be a weighted average of the unemployed worker's income and the output per person:

$$
w=\left(1-\beta^{\prime}\right) b+\beta^{\prime} A, \quad \beta^{\prime} \in(0,1) .
$$


It is assumed that the wage rate is independent of outside labor market conditions (in particular of the tightness $\theta$ ) because quitting to become unemployed is not a credible option in this environment (see for example Hall and Milgrom 2005). Unemployment income enters because during wage negotiations the worker is still unemployed and collecting compensation. ${ }^{9}$ Given the definition of $b$, we can write gross wages as

$$
w=\beta A \quad \beta \equiv \frac{\beta^{\prime}}{1-\rho\left(1-\beta^{\prime}\right)} .
$$

The job creation condition, which is used to derive the equilibrium equation for $\theta$, is $V=0$. The Bellman equations (2) and (3) yield the solution

$$
\begin{aligned}
J & =\frac{\kappa A}{q} \\
J & =\frac{(1-\beta) A}{r+\lambda-\gamma} .
\end{aligned}
$$

Combining the two gives the equation for $\theta$ :

$$
q=(s / \theta)^{\eta}=\frac{\kappa}{1-\beta}(r+\lambda-\gamma) .
$$

Higher $\gamma$ requires higher $\theta$, because with higher $\gamma$ the effective discount rate by which future profits are discounted is less. This is known as the "capitalization effect" of faster growth.

Equation (8) gives tightness in terms of parameters. It is independent of the level of productivity and of anything that is decided in goods markets. Note that unemployment compensation is one of the parameters that influence equilibrium tightness. The channel is the wage rate, because with intensity fixed, there are no search disincentives from higher compensation. A higher replacement rate implies a higher wage rate for given labor productivity, and so less job creation and lower $\theta$. Note also that taxes do not influence job creation, because of our assumptions that the wage set by the firm and worker is the gross wage, workers pay all taxes and unemployment compensation is taxed at the same rate as wages. But because workers pay the taxes, they influence the supply of hours of work to the labor market.

\footnotetext{
${ }^{9}$ Some European countries also pay compensation to families during strikes, another reason for making wages depend on unemployment income.
} 
To derive now the employment level and unemployment rate, note that with transitions $\lambda$ and $p(\theta)$ for workers, employment is

$$
N=\frac{\lambda}{\lambda+p(\theta)} L
$$

and so the unemployment rate is

$$
\begin{aligned}
u & \equiv \frac{L-N}{L}=\frac{\lambda}{\lambda+p(\theta)}, \\
p(\theta) & =s^{\eta} \theta^{1-\eta} \\
& =s\left(\frac{(1-\beta) / \kappa}{r+\lambda-\gamma}\right)^{1 / \eta-1} .
\end{aligned}
$$

The unemployment rate is fully determined by $p$ and $\lambda$ and so it is independent of decisions made in the goods market.

The model so far has shown how total employment is determined, given a participation rate $L$. The allocation of total employment between the two sectors is determined by the equality of demand and supply for the two goods. We postpone discussion of it until after we derive the demand functions. But before I move on to the goods market, I discuss here the role of search intensity in the determination of unemployment.

Introducing variable intensity by workers increases the responsiveness of search activity to shocks. To see this point consider (10). A change in one of the parameters changes the term in the brackets and so causes a change in $p$ with elasticity $1 / \eta-1$. But if $s$ is endogenous, the parameter change is likely to change $s$ in the same direction as $\theta$, because a shock that increases $\theta$ is likely to increase the rewards of search to the worker. This introduces another reason for a change in $p$. I do not derive here an optimal search intensity but illustrate the likely outcome in figure $6 .{ }^{10}$

Equation (8), which gives the optimal $\theta$ fro each $s$, is a straight line through the origin. In figure 6 it is labeled $\theta(s)$. A rise in $\gamma$ rotates it anticlockwise, giving a higher $\theta$ for each $s$. The optimal $s$ is also likely to depend positively on $\theta$, because higher $\theta$ makes search more rewarding to the worker. A curve showing the relation between the optimal $s$ and $\theta$ is drawn in figure 6 and labeled $s(\theta)$. An increase in $\gamma$ increases the expected returns of search

\footnotetext{
${ }^{10}$ See Pissarides (2000, chapter 5) for the optimal derivation of search intensity in this environment.
} 
because of a capitalization effect and so rotates this curve clockwise and to the right.

It is now easy to see the potential contribution of variable search intensity to the impact of productivity growth on unemployment. When search intensity is fixed the $s(\theta)$ line in figure 6 is vertical. So the impact of a change in $\gamma$ is always less than what it is when the $s(\theta)$ line has positive slope. In addition, the $s(\theta)$ line shifts to the right when $\gamma$ increases, further enhancing the impact of $\gamma$ on $\theta$. Intuitively, a higher $\gamma$ leads to more entry of vacancies and so to more search intensity. This feeds back to vacancy entry. In addition, search intensity increases autonomously in response to the higher $\gamma$, further increasing vacancy entry.

Unemployment compensation and wage taxes are disincentives to job search, because they reduce the net expected returns from taking a job. So with endogenous search intensity, the tax-transfer policy that I assumed in the benchmark model would lead to an anti-clockwise rotation of the $s(\theta)$ line in figure 6 and to lower equilibrium $\theta$. In addition, the fact that taxes are used to finance unemployment compensation introduces another channel through which the impact of productivity growth on unemployment becomes stronger. With budget balance $\tau$ is not a parameter but depends on unemployment. When there is a positive shock to $\gamma$ unemployment falls, and so, for given compensation level, taxation falls. This gives another incentive for job search and further job creation. In figure 6 , the impact of higher $\gamma$ on $\theta$ is enhanced by the fact that the fall in taxes that follows the rise in $\theta$ rotates the $s(\theta)$ line further to the right.

The model with fixed search intensity performs sufficiently well for my purposes and I will focus on that model. But since all taxes are likely to affect search intensity, a full modeling of the impact of taxation and unemployment compensation on unemployment needs to take the choice of intensity into account.

\section{Consumption and leisure}

Workers pool all their resources and allocate consumption on the basis of total income available, irrespective of the labor market status of each worker. Two goods are bought in the market, manufacturing $c_{m}$ and services $c_{s}$, so the budget constraint is

$$
p_{m} c_{m}+p_{s} c_{s}=w\left(1-\tau_{b}\right)(1-u+\rho u) L .
$$


Employed workers generate income $\left(1-\tau_{b}\right) w$ and unemployed workers $(1-$ $\left.\tau_{b}\right) \rho w$. The unemployment rate $u$ is given by the labor market model and it is independent of $L$. We denote in general the after-tax income generated for each labor-market participant by $y$, so in this case

$$
y \equiv w\left(1-\tau_{b}\right)(1-u+\rho u) .
$$

Note that when taxes are used only to finance unemployment compensation, $y=w(1-u)$.

The utility function is given by

$$
\begin{aligned}
\mathcal{U} & =\ln \phi+\alpha \ln \left(1-L-N_{h}\right) \\
\phi & =\left[\omega c_{m}^{\frac{\varepsilon-1}{\varepsilon}}+(1-\omega) c_{s h}^{\frac{\varepsilon-1}{\varepsilon}}\right]^{\frac{\varepsilon}{\varepsilon-1}} \\
c_{s h} & =\left[\psi c_{h}^{\frac{\sigma-1}{\sigma}}+(1-\psi) c_{s}^{\frac{\sigma-1}{\sigma}}\right]^{\frac{\sigma}{\sigma-1}}
\end{aligned}
$$

Consumers derive utility from the consumption of the three goods and from leisure time. We deduct all time spent in the market from leisure, although the unemployed may have more time to spend as leisure than the employed. The important assumption is that there is a time cost to unemployment; the fact that all the time they spend as unemployed is a time cost is a convenient simplification. The nested CES function $\phi$ ensures that the elasticity of substitution between service goods and home production is different from the elasticity of substitution between market goods. Normally $\varepsilon<1$ and $\sigma>1$, so market goods and services are poor substitutes of each other but home-produced goods are good substitutes for market-produced services (see Ngai and Pissarides, 2005).

The utility function is maximized subject to the budget constraint (11) and the production function for home goods

$$
c_{h}=A_{h} N_{h} .
$$

We show in the Appendix that the demand functions for the two market goods are,

$$
\begin{aligned}
c_{m} & =\frac{w(1-u) L}{p_{m}} \frac{1}{1+X} \\
c_{s} & =\frac{w(1-u) L}{p_{s}} \frac{X}{1+X}
\end{aligned}
$$


where

$$
X=\left(\frac{p_{s}}{p_{m}}\right)^{1-\varepsilon}\left(\frac{1-\omega}{\omega}\right)^{\varepsilon}(1-\psi)^{\frac{\sigma(\varepsilon-1)}{\sigma-1}}\left[\left(\frac{\psi}{1-\psi}\right)^{\sigma}\left(\frac{p_{s}}{p_{h}}\right)^{\sigma-1}+1\right]^{-\frac{\sigma-\varepsilon}{\sigma-1}}
$$

and $p_{h} \equiv y / A_{h}$ is an implicit price for the home-produced good, the ratio of the cost of devoting one hour to home production instead of market production to the marginal product in home production. The implicit demand function for the home-produced good is

$$
c_{h}=\left(\frac{\psi}{1-\psi}\right)^{\sigma}\left(\frac{p_{s}}{p_{h}}\right)^{\sigma} c_{s}
$$

Note that given $\varepsilon<1$, a rise in either market price reduces both market demands, whereas a rise in income increases them both. But because $\sigma>1$, a rise in the relative price of market-produced to home-produced goods, caused, say, by a uniform rise in market prices or by a fall in $p_{h}$, reduces $X$, and so reduces the consumption of market services and increases the consumption of manufacturing goods and home-produced goods.

The Appendix also shows that leisure is constant, a result that is a direct consequence of our separable logarithmic utility function, ${ }^{11}$

$$
L+N_{h}=\frac{1}{1+\alpha} .
$$

From (20), (16) and (18) we obtain

$$
\frac{N_{h}}{L}=\left(\frac{\psi}{1-\psi}\right)^{\sigma}\left(\frac{p_{s}}{p_{h}}\right)^{\sigma-1} \frac{X}{1+X}
$$

which together with (21) gives the allocation of time to market and home work.

We now have all the ingredients for the derivation of overall equilibrium: equations (17) and (18) give the demand functions used to derive the sectorial labor allocations, and (21) and (22) give the allocation of time to the labor market that determines overall employment and unemployment.

\footnotetext{
${ }^{11}$ This result mirrors the business cycle results of King, Plosser and Rebello (1988), who derived restrictions on the utility function consistent with constant average leisure.
} 


\section{Labor allocation}

With knowledge of $L$ from the preceding section we can immediately obtain total employment $N=(1-u) L$ from the labor-market model of section 4 . It remains to solve for $N_{m}$ and $N_{s}$.

The production for market goods is $A_{i} N_{i},(i=m, s)$. Some of this is used for vacancy advertising and the rest for consumption. In each sector $i$, each filled position uses up in equilibrium $(1-\beta) p_{i} A_{i}$ for vacancy advertising, a consequence of the zero profit condition for job entry. With $N_{i}$ filled positions, the value of consumption of each good $i$ is

$$
\begin{aligned}
p_{i} c_{i} & =p_{i} A_{i} N_{i}-(1-\beta) p_{i} A_{i} N_{i} \\
& =\beta p_{i} A_{i} N_{i}
\end{aligned}
$$

It follows from (17) and (18) that

$$
\begin{aligned}
N_{m} & =\frac{w(1-u) L}{\beta A_{m} p_{m}} \frac{1}{1+X} \\
N_{s} & =\frac{w(1-u) L}{\beta A_{s} p_{s}} \frac{X}{1+X}
\end{aligned}
$$

Noting that $w=\beta A_{i} p_{i}$ for both $i$, we obtain the employment shares,

$$
\begin{aligned}
n_{m} & \equiv \frac{N_{m}}{(1-u) L}=\frac{1}{1+X} \\
n_{s} & \equiv \frac{N_{s}}{(1-u) L}=\frac{X}{1+X},
\end{aligned}
$$

which confirms that $N_{m}+N_{s}=N=(1-u) L$.

This completes the description of equilibrium. As before, equations (21) and (22) give the allocation of time to home and market production. Equations (10), (26) and (27) give the allocation of market time to the three uses, unemployment, production of manufacturing goods and production of service goods. Finally, (17), (18) and (20) give the demand functions for the three consumption goods.

The variable $X$ was defined in terms of prices. But since

$$
\frac{p_{s}}{p_{m}}=\frac{A_{m}}{A_{s}} \quad \frac{p_{s}}{p_{h}}=\frac{p_{s} A_{h}}{y}=\frac{A_{h}}{\beta(1-u) A_{s}},
$$


we can express it in terms of relative productivity levels, the fraction of output claimed by workers and the rate of employment. Changes in employment and employment shares over time are driven by changes in relative productivity levels. This contrasts with the unemployment model, where changes in the unemployment rate over time are driven by changes in the rate of growth of productivity. This result is important in the comparison of the performance of the US and European economies.

An interesting and new feature of the model is that the participation rate $(L)$ depends on unemployment. Higher unemployment implies that for an extra unit of time allocated to the market by the household will generate less income - given prices and wages - and so more time is allocated to home production. In (28), this shows up as a higher implicit relative price of market goods. Also, because $n_{s} / n_{m}=X$ and $X$ falls in $p_{s} / p_{h}$, conditional on participation the share of services is lower relative to the share of manufacturing when unemployment is higher. In the traditional labor-economics literature it was noted that empirically higher unemployment was associated with lower participation, a correlation termed the "discouraged-worker effect". The traditional explanation, however, refers to the business cycle and it is that when there is unemployment, workers looking for a job become discouraged and drop out of the labor market. Here the mechanism is different and could be a feature of steady states. Higher unemployment stands for more market frictions and so households switch to more home production, where there are no frictions. Because home-produced goods are closer substitutes to services, the main market sector that suffers from this switch is the service sector. Figure 5, which used sample means for a thirty-year period, showed a weak correlation between unemployment and the participation rate across the OECD, consistent with the finding reported here.

\section{Quantitative implications: unemployment}

We showed in figure 1 a falling rate of productivity growth for the European countries and in figure 2 a rising unemployment rate. How much of the rise in unemployment can be attributed to the falling growth rate?

In our model the key equation is (10). With endogenous search intensity it is the equilibrium outcome shown in figure 6 , but I will not pursue this extension here. The zero-profit condition underlying (8) gives $\theta$, which then gives unemployment through (10). Higher rate of productivity growth in- 
creases $\theta$ and reduces unemployment. We showed in Pissarides and Vallanti (2005) that in the simple benchmark model of this paper the only parameter that really matters in the quantitative impact of productivity growth on $\theta$ is the firm's effective discount rate, $r+\lambda$. If we interpret the model literally and take $\lambda$ to be the job destruction rate a reasonable number for it is 0.1 (Davis, Haltiwanger and Schuh 1996). But with this number and $r$ equal to 4 or 5 percent, the calibrated impact of $\gamma$ on $\theta$ is tiny and much less than the impact estimated by econometricians. ${ }^{12}$ In Pissarides and Vallanti (2005) we estimated that on average a unit rise in the rate of productivity growth reduces unemployment by 1 to 1.5 percentage points. Such a big impact of growth on unemployment can be rationalized by an equilibrium model like ours only if the discount rate used by firms is small, in effect if the horizon over which firms discount the expected profit from new job creation is much longer than the expected job duration for the typical new job. I make this assumption here to derive an impact of productivity growth on unemployment that is close to the econometric estimates. As I argued previously, endogenizing search intensity could increase the impact of productivity growth, and the literature has identified some other mechanisms that enhance the impact, related to relative physical and human wealth levels and to misperceptions (respectively, Phelps, 1994, and Ball and Moffitt, 2002). I decided not to pursue this line of research in the quantitative exercise to keep the model simple. I take the shortcut of effectively calibrating $r+\lambda$ to the econometric estimates of the impact of growth on unemployment. ${ }^{13}$

Equation (10) is very simple to calibrate. I set $\eta=0.5$, in accordance with econometric estimates (Petrongolo and Pissarides, 2001) and so I get

$$
p(\theta)=\frac{s(1-\beta) / \kappa}{r+\lambda-\gamma},
$$

with $s$ constant. In accordance with the argument in the preceding paragraph, I set the discount rate $r+\lambda=0.055$, except for Italy, where it is 0.08 because productivity growth rates in that country exceeded 0.07 in the early 1960s. This choice necessitates separation of the parameter for the inflow into

\footnotetext{
${ }^{12}$ Empirically, there is a strong link between productivity growth and unemployment. See for example Phelps (1994), Fitoussi et al. (2000), Blanchard and Wolfers (2000), Ball and Moffitt (2002) and Pissarides and Vallanti (2005).

${ }^{13} \mathrm{~A}$ mechanism that could rationalize the use of a longer horizon by firms than the job destruction rate found in the empirical literature is that when the firm destroys a job in the usual sense, it does not destroy the job position but "moth-balls" it for future activation.
} 
unemployment in (10) and the $\lambda$ parameter in the discount rate. I choose the inflow into unemployment and composite of parameters in the numerator of (29) to match the sample-mean unemployment rate and an average duration of unemployment $(=1 / p(\theta))$ of a quarter in the United States and approximately two quarters in the European countries. The rate of productivity growth in these initial calculations is set at its sample mean. I then use the actual time series for the rate of productivity growth to generate a time series for unemployment.

The results are shown in figure 7 . The model does remarkably well matching the actual data. Since we calibrated the firm's discount rate to the econometric estimates, a stronger test of the performance of the model than simply comparing the two end points is its performance in tracking the dynamics of unemployment. Here it does well. In France and Germany the entire rise in unemployment is explained by the slowdown of productivity growth. In Italy productivity growth also explains a large fraction of the unemployment rise. In the early period unemployment is higher than predicted by the model, at a time when the productivity growth rate was very high, but starting in the early 1970s the model does a good job predicting the dynamics. The model also tracks the unemployment dynamics in the United States, except that it predicts a more delayed fall in unemployment in the 1990s than the one observed. In Sweden and Britain the general trend predicted by the model is also consistent with the data, but the model fails to track well the dynamics. For Sweden this is not surprising, given that for most of this period the unemployment rate was heavily manipulated by macroeconomic and labor-market policy.

Interestingly, productivity growth is a better explanation of the dynamics in the continental European countries, which are the ones that have suffered most from institutional rigidities. It is unlikely that institutional rigidities caused the fall in productivity growth in these countries, given the convergence shown in figure 1. But our results show that at comparable rates of productivity growth, the continental European countries have some 3 percentage points of unemployment more than the Unites States. This is consistent with the institutional approaches. It can be argued that the institutional structure of the continental European countries is such that a productivity slowdown has a bigger impact on unemployment there than elsewhere. ${ }^{14}$ Sec-

\footnotetext{
${ }^{14}$ Layard, Nickell and Jackman (1991, chapter 9), Blanchard and Wolfers (2000), Fitoussi et al. (2000). The OECD Jobs Study (1994) also argued for a similar mechanism, although
} 
ond, it may just have happened that as productivity growth slowed down, the continental economies increasingly made their institutions more rigid. In contrast, Britain reformed in the opposite direction and the United States took no action either before or after the slowdown. ${ }^{15}$

As an indirect test of the proposition that the impact of the productivity slowdown on unemployment was influenced by the institutional structure of the economy, I do the following. ${ }^{16}$ Recall that the inflow into unemployment and the composite of parameters in the numerator of (29) were chosen to match the sample-mean unemployment rate and an average duration of unemployment $(=1 / p(\theta))$ of a quarter in the United States and approximately two quarters in the European countries. On the assumption that the difference in duration is due to institutional rigidities, I re-calibrated the continental European unemployment series by setting duration equal to one quarter. The results are shown in figure 8. In France and Germany the model explains only about half of the observed rise in unemployment. The difference between the explained rise in these two countries and the one explained for the United States is due to the differences in the change in the exogenous variable. It is clear that the assumption that the continental European countries had persistently higher durations than the United States contributes a lot to the explanation of the big impact of the productivity slowdown on unemployment. In Italy the results are less striking - reflecting partly the poorer performance of the model in that country. The explained rise in unemployment in Italy when the initial duration of unemployment is reduced to one quarter is of the same order of magnitude as the observed rise.

Whichever institutional story is true, the conclusion remains that the reason for the much lower European unemployment rates in the 1960s appears to be the European economies' faster rates of growth associated with catchup, as Myers (1964) and other early observers had anticipated.

not specifically with reference to productivity growth.

${ }^{15}$ Despite the apparent coincidences required for this argument to go through, it is not implausible. See for example Nickell, Nunziata and Ochel (2005), who argue that the unemployment rise is due to institutional change.

${ }^{16}$ I am grateful to Richard Rogerson for suggesting this test. 


\section{Hours of work and structural change}

The North Atlantic divide on hours of work and structural change is more difficult to replicate with the benchmark model than unemployment proved to be. We begin by looking at the contribution of productivity growth to the observed changes.

The key to the cross-country comparison of hours in the benchmark model are the two relative-price variables. These drive the dynamics of $X$, the ratio of the employment share of services to manufacturing, and $N_{h} / L$, the ratio of home work to market work. But there is a problem here. In Europe the ratio of service to non-service employment has risen much faster than in the United States, and market hours have fallen by much more than in the United States. So if the model is to account for these differentials both $X$ and $N_{h} / L$ in Europe have to rise much faster than in the United States. Because technological progress in home production is not likely to have exceeded technological progress in the market (see below for some data), the price ratio $p_{s} / p_{h}$ is likely to have fallen over time. A falling $p_{s} / p_{h}$ can explain a falling supply of hours to market services and to overall market work. Whereas the latter is consistent with the data, if the model is to also explain the rise in the relative share of services it needs a much faster growth in the relative price of services, $p_{s} / p_{m}$, in Europe than in the United States. Available data, however, show small differentials in the evolution of $p_{s} / p_{m}$ between Europe and the United States. Although the United States has had the smallest rise in our sample, the differential between the United States and the countries in our sample over the thirty year period is about 10 percent. The differences in aggregate productivity growth associated with catch-up do not appear to be reflected in differential rates of productivity growth across sectors.

Rogerson (2004), who was confronted with this problem, did not use European productivity data. In order to replicate the structural pattern in 1956, his starting year, he assumed that European technology in 1956 was 38 years behind the United States (as aggregate hourly productivities indicate). He then derived a manufacturing productivity in Europe that was only 40 percent of US productivity but a service productivity that was 62 percent of US productivity. Available sectorial productivity data, however, do not justify such big differentials, at least for the post-1970 period. If this were the case, and the speed of catch-up in Europe was more or less proportional to the gap, relative manufacturing-to-service productivity in Europe between 1970 and 2000 would have to rise by 30 percent over and above the US rise. 
But the observed figure is only about 10 percent.

Data for Europe on home production are not as comprehensive as for the United States. I use US data from Ramey and Francis (2005) to derive a relative-price series for market and home production. I choose $\sigma=2$ and $\varepsilon=0.3^{17}$, make use of published employment data for $n_{s} / n_{m}$ to compute a time series for $X$ and of the Ramey-Francis data to compute $N_{h} / L$. These data and (19) and (22) give me a time series for $(\psi /(1-\psi))^{\sigma}\left(p_{s} / p_{h}\right)^{\sigma-1}$. Letting $p_{s} / p_{h} \equiv 1$ in 1970 , I compute a value for $\psi=0.52$ from the initial values of the series for $N_{h} / L$ and $X$. The derived implicit price ratio $p_{s} / p_{h}$ for this value of $\psi$ for the United States is shown in figure 9. As expected, the relative price of market services is falling, at an average rate of 1 percent a year. From (28), if the share of labor $\beta$ is constant, we also derive that the productivity of market services has been rising at an average rate of 1 percent a year faster than the productivity of home production.

Now, if I use the computed series for $p_{s} / p_{h}$ and assume that in 1970 $p_{s} / p_{m} \equiv 1$, I derive from (19) $\omega=0.024$. With these parameters and the computed time series for $p_{s} / p_{h}$, I use the ratio of actual data for hourly laborproductivity growth in the service sector and in the rest of the economy to derive a proxy for $p_{s} / p_{m}$ and from these two get a prediction for the evolution of relative employment shares. In the United States this prediction is almost perfect, see figure 10(a). In order to show the predictive power of the model I show in figure 10(a) the actual series for $X \equiv n_{s} / n_{m}$, the the predicted series (which virtually coincides with it) and the series generated by holding $p_{s} / p_{m}$ constant. Clearly, the series $p_{s} / p_{m}$, which was not used in the computations to this point, has a lot of predictive power.

In the absence of European data on home production, I use the relation $p_{s} / p_{h}=A_{h} / A_{s} \beta(1-u)$ for the United States to derive a series for $A_{h} / \beta A_{s}$ for the European countries. Using country data for $1-u$ and assuming that $\beta$ is common, I derive a relative price series for each European country. Because European unemployment has risen by more than US unemployment, the computed price series for Europe falls less fast than the US series. But the slower fall makes the prediction for the rise in the service share worse, because slower fall in $p_{s} / p_{h}$ implies a fall or slower rise in overall employment that has its biggest impact on services. So although the joint treatment of hours of work and unemployment contributes to the explanation of the faster

\footnotetext{
${ }^{17}$ See Rogerson (2005) and Ngai and Pissarides (2005) for the reasons for choosing these numbers.
} 
decline of overall hours of work in Europe, it goes against the prediction of a faster rise in the European service share.

As another check, I use available data on productivity growth in services in Europe to adjust the relative price $p_{s} / p_{h}$, effectively assuming that home technology in Europe is the same as in America but service market technology is as in the data. Doing this accelerates the fall in $p_{s} / p_{h}$ in Europe, because of the higher rate of service productivity growth associated with catch-up. This improves substantially the model prediction for the rise in the relative service share, but only at the expense of home production. By forcing a bigger fall in relative prices we are implying that the market-production technology has improved faster than the home-production technology, and so more employment should move from the home to the market. So this extension completely misses the fall in overall market hours. In some cases it predicts that European hours of work should be rising.

This points to some other explanation, unrelated to technology, for the simultaneous rise of the relative service share in Europe and the decline of total hours of work. European countries had a bigger agricultural sector in 1970 than the United States had, so the movement of labor from agriculture to services may have contributed to the rise of the service sector. But this cannot be an explanation for Britain, which had a comparable agricultural sector to the United States (although in Britain the model predicts very accurately the relative rise of the service sector). International trade is a more likely explanation, as competition from Japan and other countries led to the shift of employment out of manufacturing and into services or non-employment in Europe. Barriers to market activity that are stronger in manufacturing are also an explanation. One such barrier is trade union activity, which is more prominent in manufacturing than in services. ${ }^{18}$ Finally, the fact that Europe and the United States started from a very different sectorial employment distribution in 1970, with Europe having much lower service employment relative to manufacturing and agriculture, has to play a role. When the differences in the sectorial productivity growth rates are small it can take many years for the sectorial employment distribution to reach a certain target. So if the European economies are lagging the United States in this process, the relative size of their service sectors should be increasing faster as they catch

\footnotetext{
${ }^{18} \mathrm{I}$ argued in Pissarides (2006) that the decline of trade union power has played a role in the fall in unemployment and rise in employment in Britain. Alesina, Glaeser, Sacerdote (2005) also argued for the importance of trade union power in the determination of European outcomes.
} 
up (Ngai and Pissarides, 2005).

\section{The role of taxation}

Another possible explanation for the differential performance of the United States and Europe is taxation, an explanation that has attracted recent attention in the literature. ${ }^{19}$ The issue of taxation and its effect on labor market outcomes is too big to be studied in detail here. The assumptions made about the type of taxation - whether it is on income or on spending - and the way the revenue is distributed by the government - whether as a non-distortionary lump-sum transfer or as a distortionary subsidization of some economic activity - are important determinants of the impact of taxation on outcomes. In addition, in order to do full justice to the issue of taxation we need a more complete theory of the incidence of taxation than presented here. In our labor market model all taxes are paid by workers, and so taxation does not distort job creation, except to the extent that it influences workers' search incentives.

The only taxes assumed so far in the model are the ones used to finance unemployment compensation. We derived an important result that generalizes to other taxes: if the tax revenue is returned to individuals conditional on participation in the labor market taxes do not influence participation. But of course, they may influence wages or hours of work by increasing unemployment. To some extent the higher unemployment in Europe at given productivity growth rates must be due to the more generous unemployment compensation in Europe, although the estimated elasticities are small. ${ }^{20}$ Nickell, Nunziata and Ochel (2005) summarize the results of cross-country studies by saying that a 10 percentage point rise in the replacement rate increases unemployment by 1.1 percentage points. In OECD data the replacement rate

\footnotetext{
${ }^{19}$ See Nickell and Layard (1999) for a summary of earlier contributions, Daveri and Tabellini (2000), Prescott (2002) and Rogerson (2004) for models that give a large role to taxation in European countries, and Nickell (2004) for a recent summary of the econometric evidence.

${ }^{20}$ Narandenathan, Nickell and Stern (1984) estimate on British data an elasticity of the probability of leaving unemployment (our $p$ ) with respect to unemployment compensation of -0.4. Meyer (1989) estimates on US data -0.9 , but this elasticity depends on the level of the replacement rate and his sample consisted of individuals with high replacement rates. When adjusted for this his estimate is comparable to the British estimate. See also the discussion in Nickell and Layard (1999) for cross-country evidence.
} 
in the United States is 15-20 percentage points less than in the continental European countries, so this could potentially explain some 1.5-2 percentage point unemployment differentials at common productivity growth rates. But differences in replacement rates within Europe are not as big and yet there are large unemployment differences. Finally, although unemployment compensation can explain some unemployment differences, it cannot explain the large differences in hours or work due to differences in participation rates.

Other taxes that do not have an impact on participation are taxes used to finance "active labor market policies". These are policies mainly designed to get the unemployed back to work, or to provide subsidized training for the employed. The Scandinavian countries are the biggest spenders on these measures, but other European countries spend a lot on them too. Especially those that have generous unemployment compensation, usually also have generous active measures to offset the impact of unemployment compensation on unemployment.

With these caveats in mind, I now add to the model taxes that yield revenue that is returned as an unconditional non-distortionary lump sum transfer to households, denoted by $\tau_{T}$, and taxes whose revenue is spent on things that are not substitutes for goods in households' utility functions, denoted by $\tau_{g} \cdot{ }^{21}$ I continue to assume that all taxes are proportional taxes on wages. The household's budget constraint now is

$$
p_{m} c_{m}+p_{s} c_{s}=w\left(1-\tau_{b}-\tau_{T}-\tau_{g}\right)(1-u+\rho u) L+T,
$$

where $T$ is the lump-sum transfer. I denote $\tau_{b}+\tau_{T}+\tau_{g} \equiv \tau$, so now

$$
y=w(1-\tau)(1-u+\rho u)
$$

which by budget balance is equal to $w\left(1-\tau_{T}-\tau_{g}\right)(1-u)$. In light of our earlier discussion, the tax $\tau_{b}$ should now include all taxes that are used to raise revenue spent on labor market measures. I assume for simplicity that the tax instruments $\tau_{T}$ and $\tau_{g}$ are exogenous, and the budget is balanced through changes in the spending that is not in utility functions or in $T$.

Taxes now have an impact on the allocation of time and the demand for goods. The derivations in the Appendix are unaltered by the introduction of

\footnotetext{
${ }^{21}$ If the government spent the tax revenue on goods that are perfect substitutes to privately-purchased goods, such as health care, the impact of taxes would be the same as the one of a lump-sum transfer.
} 
taxes up to (46), which now becomes,

$$
1=\lambda y\left(L+N_{h}\right)+\lambda T \text {. }
$$

Combining with (41) we get a new condition for the supply of work time,

$$
L+N_{h}=\frac{y-\alpha T}{y(1+\alpha)}
$$

By budget balance $T=\tau_{T} w(1-u)$, so (32) becomes

$$
L+N_{h}=\frac{1}{1+\alpha}\left(1-\frac{\alpha \tau_{T}}{1-\tau_{g}-\tau_{T}}\right) .
$$

If $T=\tau_{T}=0$, i.e., no tax is returned as a lump-sum transfer, leisure is still constant and independent of taxation. The disincentives of taxes on the supply of labor are due entirely to the component of the tax that is transferred, $\tau_{T}$. Prescott (2002) and Rogerson (2004) derived large disincentive effects of taxes partly because they assumed that all taxes are returned as lump-sum transfers, i.e., in their models $\tau_{T}=\tau$. Income and substitution effects for taxes not returned offset each other because of the logarithmic utility function. But if $\tau_{T}>0$, other taxes also cause disincentives, and if $\tau_{g}>0$, the disincentives of marginal changes in transfers are bigger.

Reasoning as before for the demand for goods we obtain,

$$
\begin{aligned}
c_{m} & =\frac{w(1-u)\left(1-\tau_{g}\right) L}{p_{m}} \frac{1}{1+X} \\
c_{s} & =\frac{w(1-u)\left(1-\tau_{g}\right) L}{p_{s}} \frac{X}{1+X}
\end{aligned}
$$

so not surprisingly, only the "wasteful" component of taxation reduces consumption demands, because it reduces the income of individuals. The relative allocation of demand to home consumption and market consumption in (20) remains unaltered for given prices, but relative prices are distorted by taxation. Whereas the relative prices of market goods are the same as before, the implicit price of home-produced goods falls, since by definition $p_{h}=y / A_{h}$ and $y$ is lower with taxation. So we now have,

$$
\frac{p_{s}}{p_{h}}=\frac{A_{h}}{\beta\left(1-\tau_{g}-\tau_{T}\right)(1-u) A_{s}} .
$$


The introduction of taxes therefore increases the relative price of market goods and reduces $X$. This change works against the requirement that the relative service share should increase. Intuitively, taxes make home production more attractive and this affects adversely service employment by more than non-service employment, because of the better substitution possibilities between home production and market services.

Taxation may, however, help explain the fall in market hours. The equation for the allocation of time to home production becomes,

$$
\frac{N_{h}}{L}=\frac{1-\tau_{g}}{1-\tau_{g}-\tau_{T}}\left(\frac{\psi}{1-\psi}\right)^{\sigma}\left(\frac{p_{s}}{p_{h}}\right)^{\sigma-1} \frac{X}{1+X} .
$$

This equation and (33) are solved for the allocation of time with taxation. Taxes increase leisure and home production, so the impact on market work is likely to be substantial. We note that the bigger the fraction of taxes returned as lump sum, the bigger the relative impact on leisure and the smaller the relative impact on home production.

In the absence of readily-available information on the fraction of tax revenue spent on different measures, figure 11 reports the results of running the model with taxes, by following Prescott (2002) and Rogerson (2004) and assuming that all taxes are returned as an unconditional lump-sum transfer. Given our discussion of labor market policies, this assumption is clearly inappropriate for all countries, but especially for Sweden. Results are mixed. First, we note that under this assumption the supply of market hours is very sensitive to taxation. Econometric studies did not find such a big impact of taxation on employment, which is evidence against this type of modeling for taxes. In the case of Sweden the model breaks down. Taxes increased so much between 1970 and 1985 that the prediction is that hours of work should drop to negative numbers. In the case of Italy taxes fail to get the dynamics of hours but they predict the 2000 level fairly accurately. This result points to the risks of evaluating the impact of taxation by comparing single points. But taxes improve substantially the prediction of market hours for France and Germany.

\section{Concluding remarks}

What can we make of our theoretical and quantitative results? First, about the theory: bringing together the model of unemployment on the one hand, 
and hours of work on the other, has some advantages but not enough to make individual studies of each question in isolation obsolete. The overall participation rate can be taken as exogenous in the unemployment model, and unemployment can be included as a variable that summarizes labor-market frictions in the participation model. But apart from these connections, the models can be solved independently from each other. The important productivity and taxation variables influence the outcome of each model differently. Unemployment is influenced by the rate of growth of productivity, but the supply of hours is influenced by productivity in services relative to other market sectors and to home production. Home production plays an important role in the responsiveness of hours of work to exogenous shocks, although when there is distortionary taxation there are substitutions between hours of work and both leisure and home production. Taxation overall has less impact on unemployment than on participation, but taxation that is used to finance spending that is conditional on labor-market participation, such as unemployment compensation or active labor market measures, influences unemployment but not the supply of hours of work to the labor market.

In the quantitative analysis I showed that the main reason for the reversal in the unemployment fortunes of Europe and North America is in productivity growth. In the post-war era and up to the 1970s productivity growth in most European countries was fast because of technological catch-up. This explains why unemployment was low. But some role for institutions remains, in that when productivity growth rates converged, equilibrium unemployment in some European countries, especially in the three big continental countries, settled at some 2-3 percentage points above US unemployment.

The model is less successful at explaining the reasons for the very different behavior of hours of work and sector employment shares in Europe and America. Sectoral differentials in productivity growth explain well the US employment distribution. But if similar assumptions are made about preferences and institutions in Europe, the predicted differences due to productivity differentials are too small compared with the observed differences in the dynamics of the service share. Accounting for institutional differences is one way forward. The results of introducing taxation in the model are mixed, because of the difficulty of distinguishing different types of taxes in the data. But higher taxes in Europe must have contributed to the fall in hours. Another factor that may be important is the difference in the initial employment distribution in each case. But for this to matter in a model there must be either differences in the relative productivity growth rates associated 
with the initial distribution or some other slow changing state variable, like capital. We showed that differences in the relative productivity growth rates are not sufficiently big to account for his, so further analysis of this issue requires a model with a slow-changing state variable, like physical capital or barriers to economic activity that slow down labor mobility.

\section{Appendix}

\subsection{Derivation of optimal consumption and time al- locations}

Let $\phi_{i}$ denote the partial derivative of $\phi$ with respect to $c_{i}(i=m, s, h), \lambda$ be the Lagrangian multiplier for (11) and $\mu$ the multiplier for (16). Then the first-order conditions for $c_{m}, c_{s}, c_{h}, L$ and $N_{h}$ are, respectively

$$
\begin{gathered}
\frac{\phi_{m}}{\phi}=\lambda p_{m} \\
\frac{\phi_{s}}{\phi}=\lambda p_{s} \\
\frac{\phi_{h}}{\phi}=\mu \\
\frac{\alpha}{1-L-N_{h}}=\lambda y \\
\frac{\alpha}{1-L-N_{h}}=\mu A_{h} .
\end{gathered}
$$

From (40), (41) and (42) we obtain

$$
\frac{\phi_{h}}{\phi}=\frac{\lambda y}{A_{h}},
$$

and because $\phi$ is homogeneous of degree 1 ,

$$
\begin{aligned}
1 & =\frac{\phi_{m}}{\phi}\left(c_{m}+\frac{\phi_{s}}{\phi_{m}} c_{s}+\frac{\phi_{h}}{\phi_{m}} c_{h}\right) \\
& =\lambda\left(p_{m} c_{m}+p_{s} c_{s}+\frac{y}{A_{h}} c_{h}\right) .
\end{aligned}
$$


Making use of the two constraints, (11) and (16), we obtain,

$$
1=\lambda y\left(L+N_{h}\right) .
$$

Combining (46) and (41) we get (21).

Next, we compute the demand functions. From (15), (39) and (40) we obtain

$$
\frac{\psi}{1-\psi}\left(\frac{c_{s}}{c_{h}}\right)^{1 / \sigma}=\frac{y}{p_{s} A_{h}}=\frac{p_{h}}{p_{s}} .
$$

where $p_{h} \equiv y / A_{h}$ is the implicit price of the home-produced good. From (15) we get,

$$
\frac{c_{s h}}{c_{s}}=(1-\psi)^{-\frac{\sigma}{\sigma-1}}\left[\left(\frac{\psi}{1-\psi}\right)^{\sigma}\left(\frac{p_{s}}{p_{h}}\right)^{\sigma-1}+1\right]^{\frac{\sigma}{\sigma-1}} .
$$

from (38) and (39) we get,

$$
\frac{\omega}{(1-\psi)(1-\omega)}\left(\frac{c_{s h}}{c_{s}}\right)^{\frac{1}{\varepsilon}-\frac{1}{\sigma}}\left(\frac{c_{s}}{c_{m}}\right)^{\frac{1}{\varepsilon}}=\frac{p_{m}}{p_{s}},
$$

and so,

$$
\frac{p_{s} c_{s}}{p_{m} c_{m}}=X
$$

where $X$ is defined in (19). By solving now (50) and the budget constraint (11) for the two unknowns $c_{m}$ and $c_{s}$ we get the demand functions for the two market goods in (17) and (18). From (47) we obtain the implicit demand function in (20).

\section{References}

[1] Aguiar, M. and E. Hurst (2005). "Measuring Leisure: Evidence from Five Decades of Time Use Surveys", unpublished paper, University of Chicago.

[2] Alesina, A., E. Glaeser, and B. Sacerdote (2005). "Work and Leisure in the US and Europe: Why so Different?" NBER Macroeconomics Annual, 20: $1-64$.

[3] Andolfatto, D. (1996). "Business Cycles and Labor Market Search." American Economic Review 86: 112-132. 
[4] Ball, L. and R. Moffitt (2002). "Productivity Growth and the Phillips Curve." In The Roaring Nineties: Can Full Employment be Sustained?, edited by A. B. Krueger and R. Solow. New York: Russell Sage Foundation.

[5] Blanchard, O. J. (2006). "European Unemployment: The Evolution of Facts and Ideas." Economic Policy, 21(45): 5-59.

[6] Blanchard, O. J. and J. Wolfers, (2000), "The Role of Shocks and Institutions in the Rise of European Unemployment: The Aggregate Evidence", The Economic Journal, 110, 1-33.

[7] Bruno, M. and J. D. Sachs (1985). Economics of Worldwide Stagflation. Cambridge, Massachusetts: Harvard University Press.

[8] Daveri, F. and G. Tabellini (2000). "Unemployment, Growth and Taxation in Industrial Countries." Economic Policy 30: 49-90.

[9] Davis, S. J., J. C. Haltiwanger, and S. Schuh (1996). Job Creation and Destruction. Cambridge, MA, MIT Press.

[10] den Haan, W., G. Ramey, and J. Watson. (2000). "Job Destruction and Propagation of Shocks." American Economic Review 90: 482-498.

[11] Downie, J. (1964). "The Importance of Knowing What You Want." Unemployment and the American Economy. A. M. Ross, ed., New York: John Wiley and Sons.

[12] Fitoussi, J.-P., D. Jestaz, E. S. Phelps and G. Zoega (2000). "Roots of the Recent Recoveries: Labor Reforms or Private Sector Forces?" Brookings Papers on Economic Activity 1: 237-291.

[13] Freeman, R. and R. Schettkat (2005), "Marketization of Household Production and the EU-US Gap in Work', Economic Policy, 20(41): 5-50.

[14] Gordon, R. J. (1997). "The Time-Varying NAIRU and its Implications for Economic Policy." Journal of Economic Perspectives 11: 11-32.

[15] Greenwood, J., A. Seshadri and M. Yorukoglu (2005). "Engines of Liberation." Review of Economic Studies 72: 109-133. 
[16] Hall, R. E. (2006). "Job Loss, Job Finding, and Unemployment in the U.S. Economy over the Past Fifty Years." NBER Macroeconomics Annual, 20: 101-137.

[17] Hall, R. E. and P. R. Milgrom (2005). "The Limited Influence of Unemployment on the Wage Bargain." Stanford University mimeo.

[18] King, R., C. Plosser and S. Rebelo (1988). "Production, Growth and Business Cycles I. The Basic Neoclassical Model." Journal of Monetary Economics 28: 195-232.

[19] Layard, R., S. Nickell, and R. Jackman (1991). Unemployment: Macroeconomic Performance of the Labour Market. Oxford: Oxford University Press.

[20] Layard, R. and S. Nickell (1999). "Labor Market Institutions and Economic Performance." Handbook of Labor Economics. O. Ashenfelter and D. Card, eds., Amsterdam: North-Holland. 3C.

[21] Maddison, A. (1995). Monitoring the World Economy 1892-1992. Development Centre studies, OECD.

[22] Merz, M. (1995). "Search in the Labor Market and the Real Business Cycle." Journal of Monetary Economics 36: 269-300.

[23] Meyer, B. D. (1990). "Unemployment Insurance and Unemployment Spells." Econometrica 58: 757-782.

[24] Mortensen, D. T. and C. A. Pissarides (1999). "Job Reallocation, Employment Fluctuations, and Unemployment." Handbook of Macroeconomics. M. Woodford and J. Taylor, eds., Amsterdam:, North-Holland.

[25] Myers, R. J. (1964). "Unemployment in Western Europe and the United States." Unemployment and the American Economy. A. M. Ross, ed. New York: John Wiley and Sons.

[26] Narendranathan, W., S. Nickell, and J. Stern (1985). "Unemployment Benefits Revisited." Economic Journal 95: 307-329.

[27] Ngai, L. R. and C. A. Pissarides (2005). "Trends in Hours and Economic Growth." CEPR Discussion Paper 4763. 
[28] Nickell, S. (1997). "Unemployment and Labor Market Rigidities: Europe versus North America." Journal of Economic Perspectives: 55-74.

[29] Nickell, S. (2004). "Employment and Taxes", CEP Discussion Paper No 634.

[30] Nickell, S., L. Nunziata, and W. Ochel. (2005). "Unemployment in the OECD since the 1960s. What Do we Know?" Economic Journal 115: $1-27$.

[31] Nickell, S. J. and R. Layard (1999). "Labor Market Institutions and Economic Performance". Handbook of Labor Economics. O. Ashenfelter and D. Card, editors. Amsterdam, North-Holland. 3C: 3029-3084.

[32] Petrongolo, B. and C. A. Pissarides (2001). "Looking Into the BlackBox: A Survey of the Matching Function", Journal of Economic Literature 39, 390-431.

[33] Phelps E. S. (1994). Structural Slumps, The Modern Equilibrium Theory of Unemployment, Interest and Assets, Cambridge MA: Harvard University Press.

[34] Pissarides, C. A. (1986). "Unemployment and Vacancies in Britain." Economic Policy 3: 499-559.

[35] Pissarides, C. A. (2000). Equilibrium Unemployment Theory, Cambridge, Mass: MIT Press.

[36] Pissarides, C. A. (2006). "Unemployment in Britain: A European Success Story." Structural Unemployment in Western Europe: Reasons and Remedies. M. Werding, ed. , Cambridge MA, London UK: MIT Press.

[37] Pissarides, C. A. and G. Vallanti (2005). "The Impact of TFP Growth on Steady-State Unemployment." International Economic Review, forthcoming.

[38] Prescott, E., (2004). "Why Do Americans Work So Much More than Europeans?" Quarterly Review of the Federal Reserve Bank of Minneapolis, July, 2-13.

[39] Ramey, V. and N. Francis. (2005). "A Century of Work and Leisure." Working Paper. 
[40] Rogerson, R. (2004). "Structural Transformation and the Deterioration of European Labor Market Outcomes." Working Paper.

[41] Shimer, R. (2005). "Reassessing the Ins and Outs of Unemployment", unpublished paper 
Figure 1

Hourly productivity growth rates

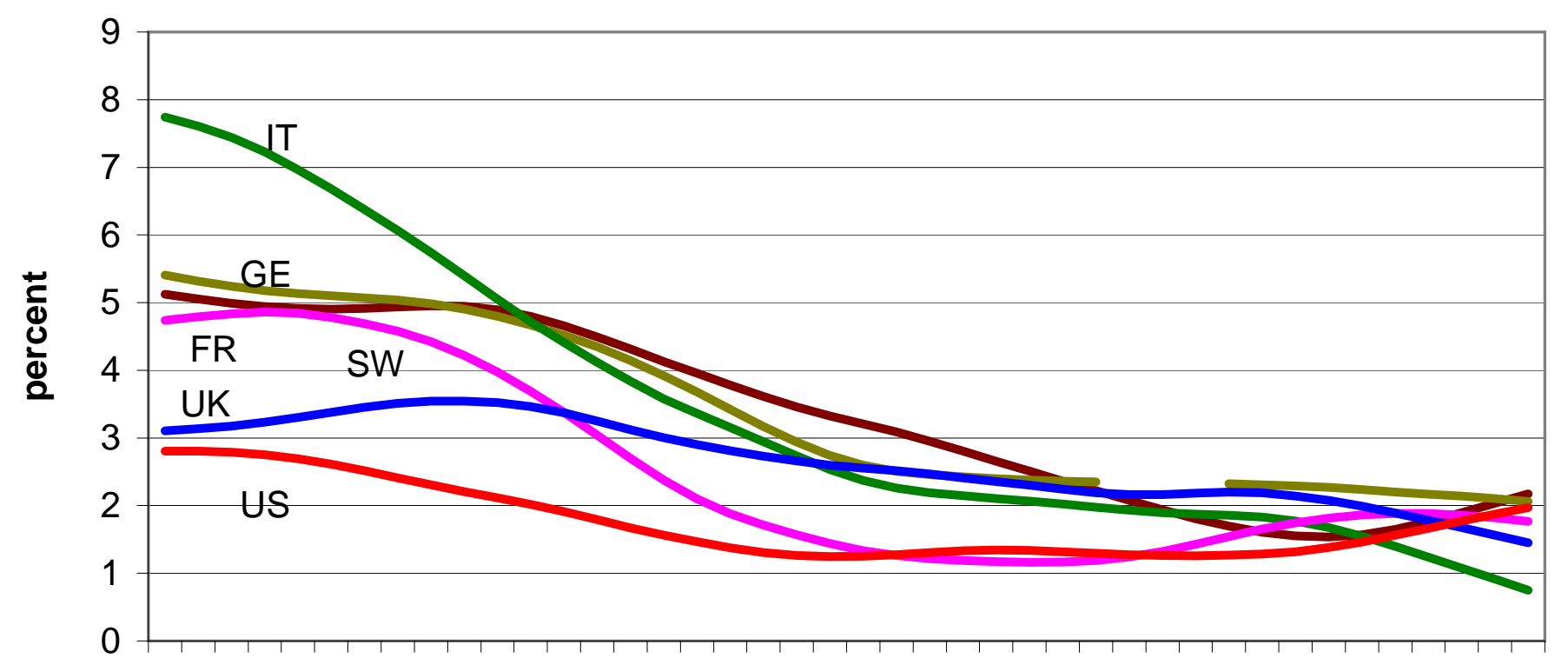

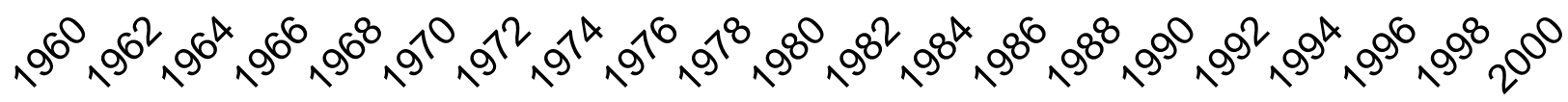

Figure 2

\section{Unemployment Trends}

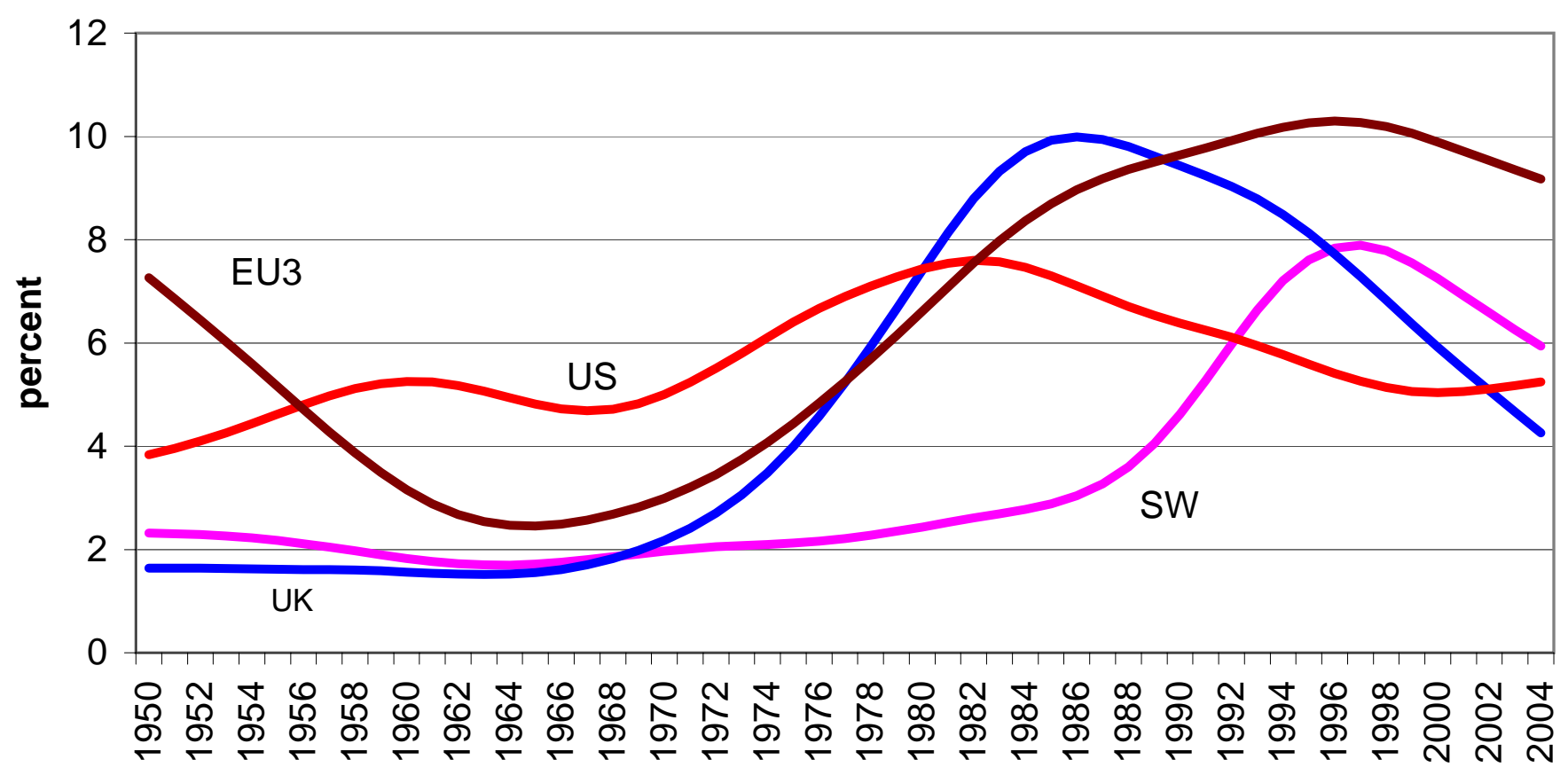


Figure 3

Trends in annual hours of work

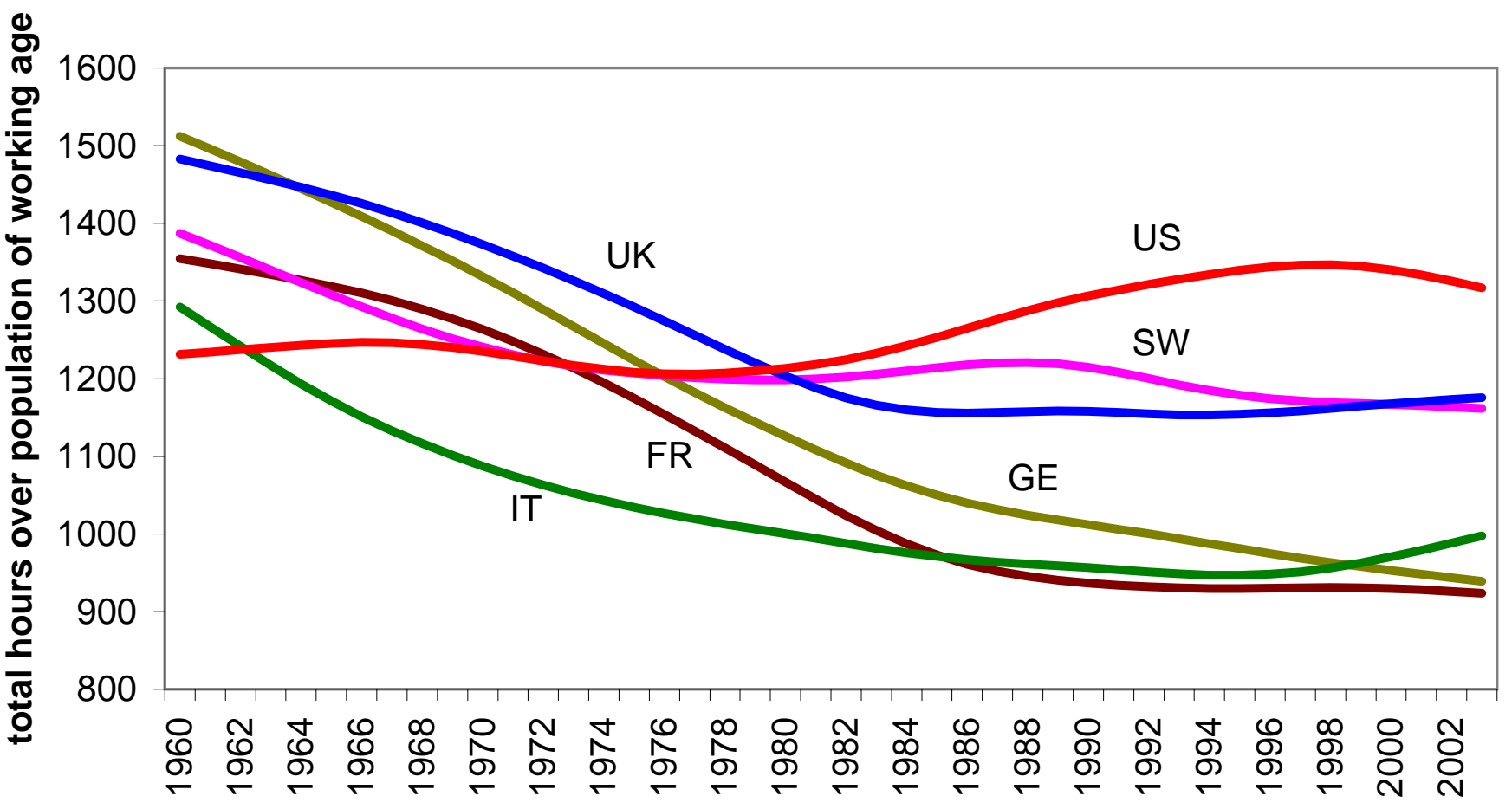

Figure 4

Annual hours of work in services

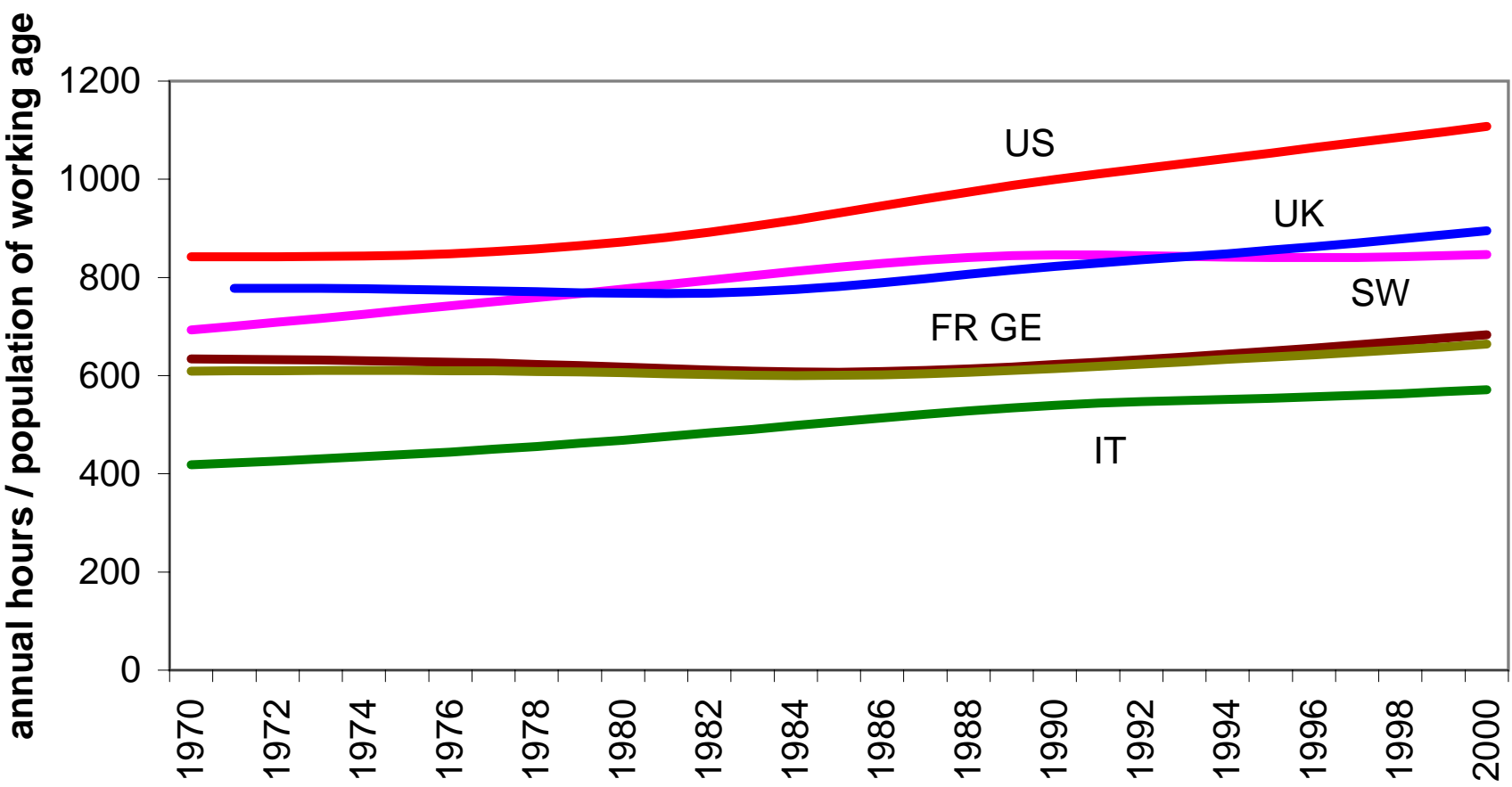


Figure 5

Unemployment rate vs participation rate, 1970-98

sample means, 19 OECD countries

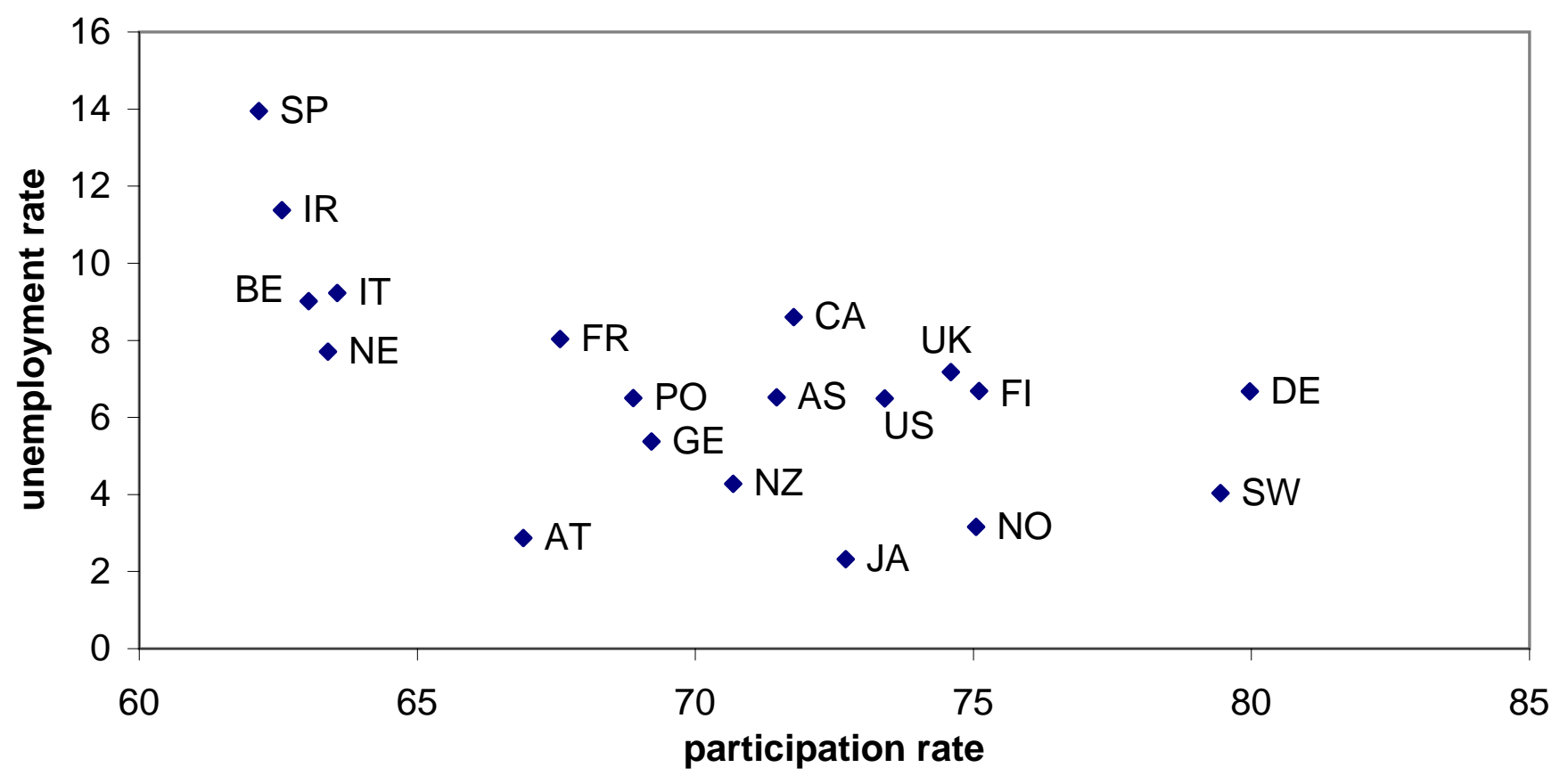


Figure 6

The impact of higher productivity growth on labor market equilibrium with endogenous search intensity

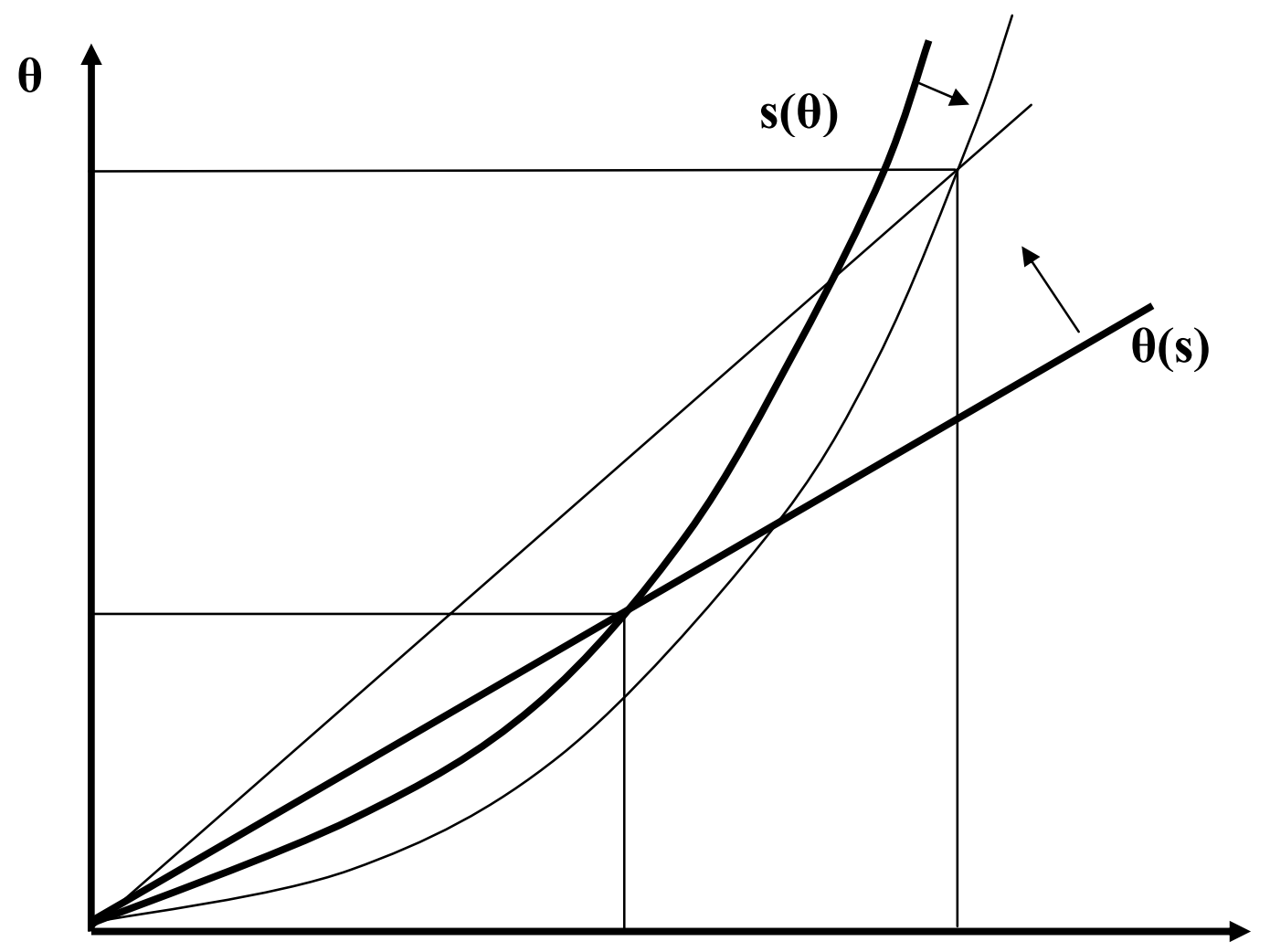


Figure 7

Predicted and actual unemployment
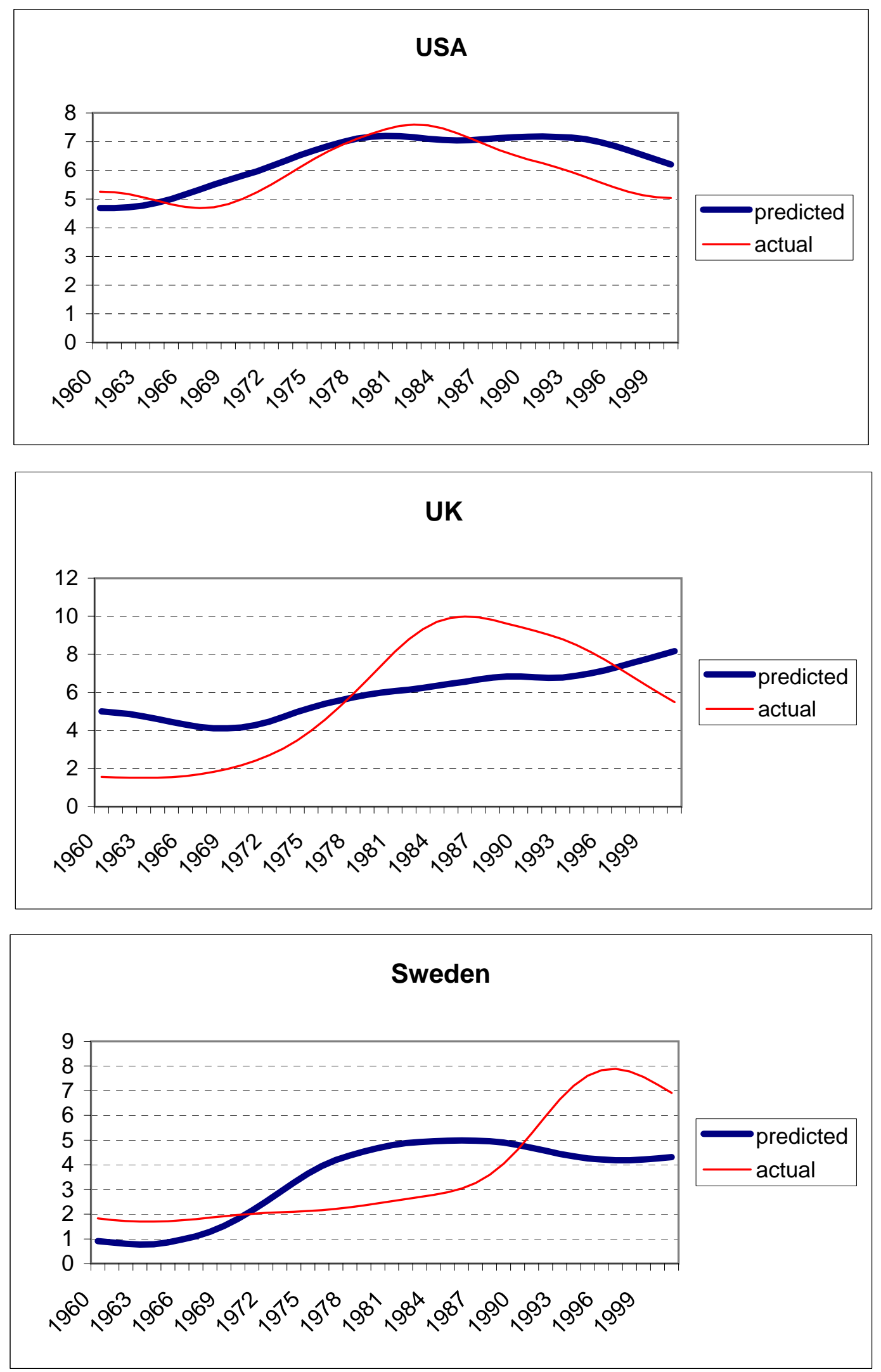
Figure 7, cont.

Predicted and actual unemployment
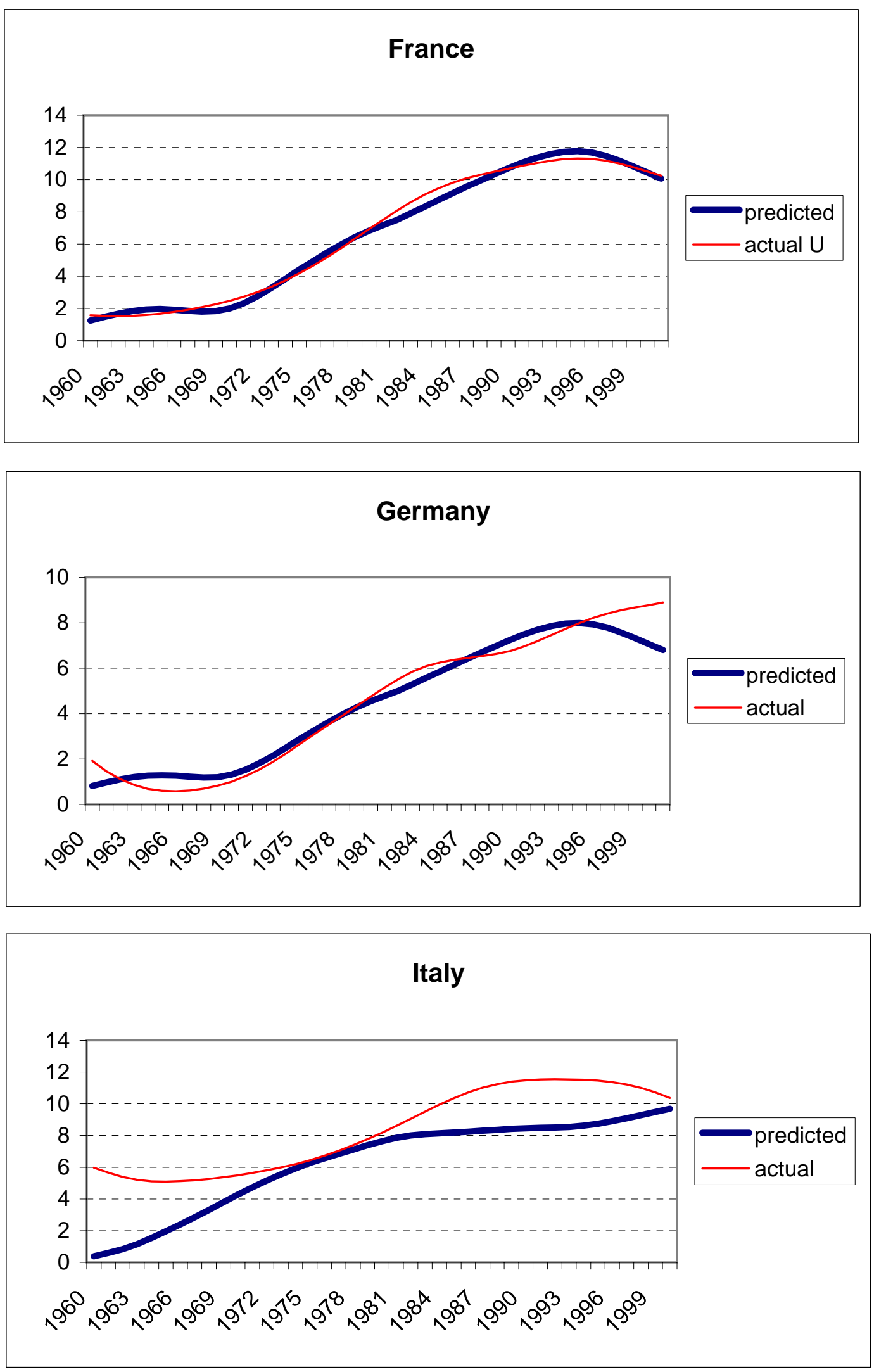
Figure 8

Predicted and actual unemployment with US-like durations
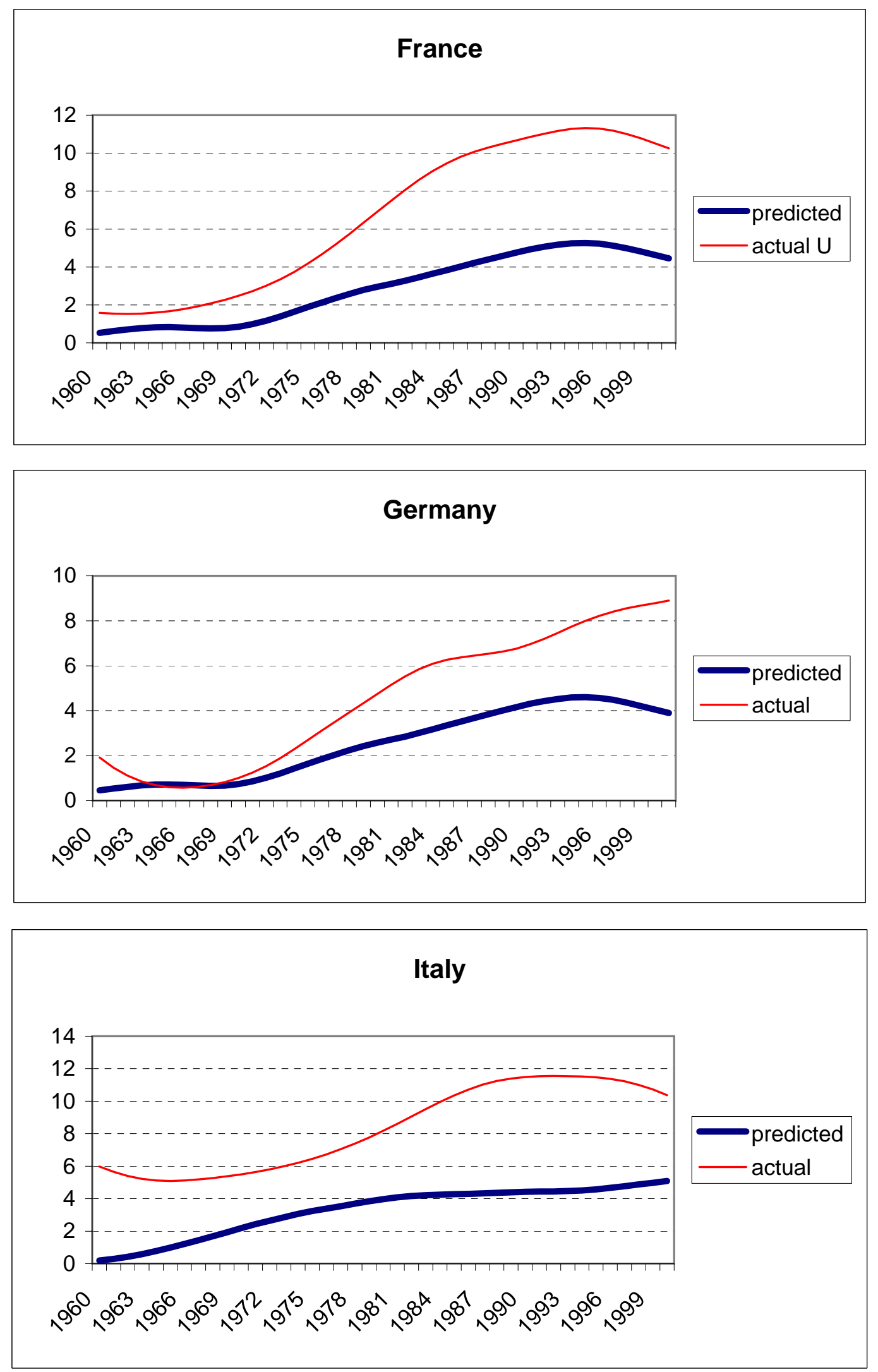
Figure 9

The implicit price of market to home services, United States

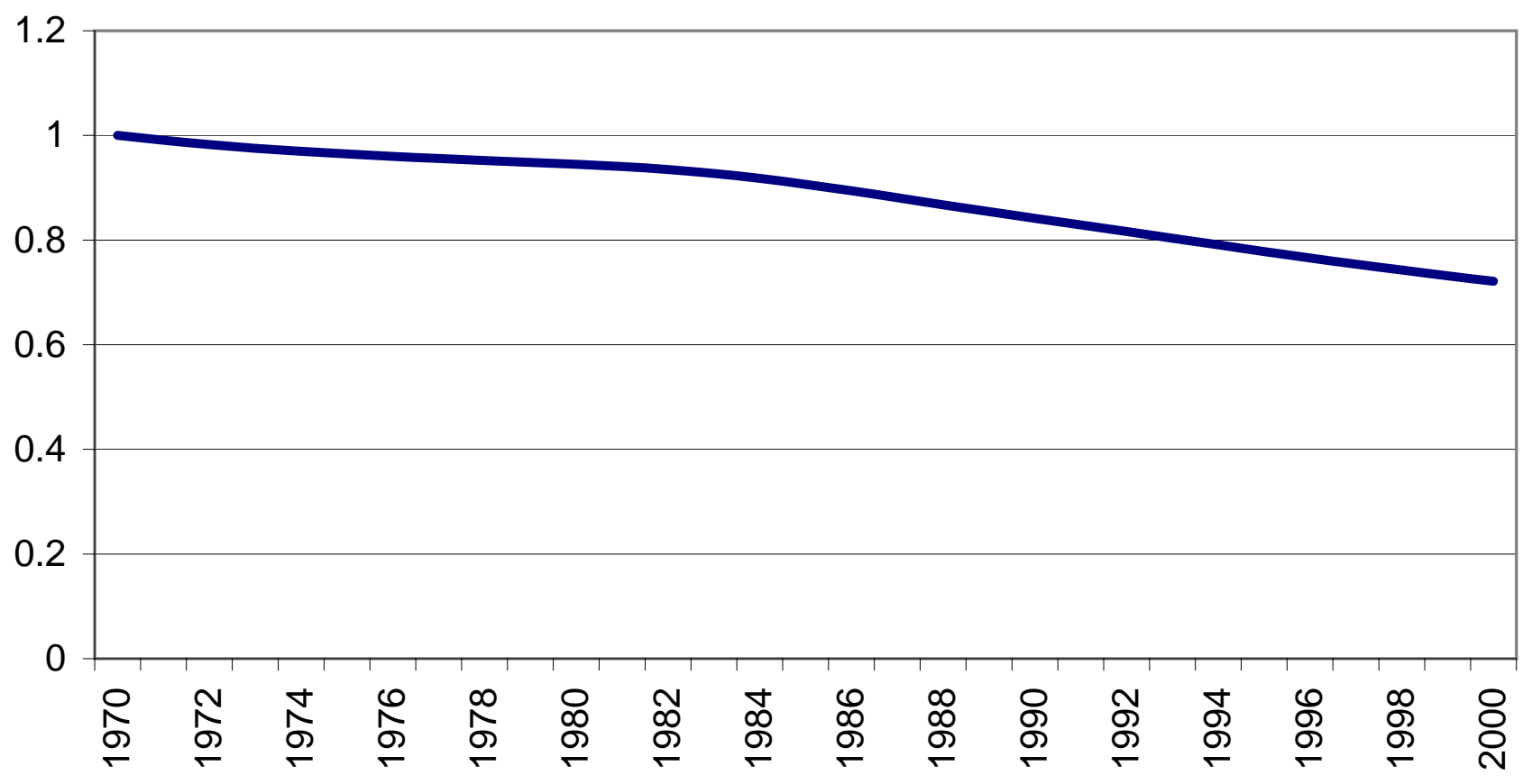


Figure 10 (a)

Predicted and actual service/nonservice employment share

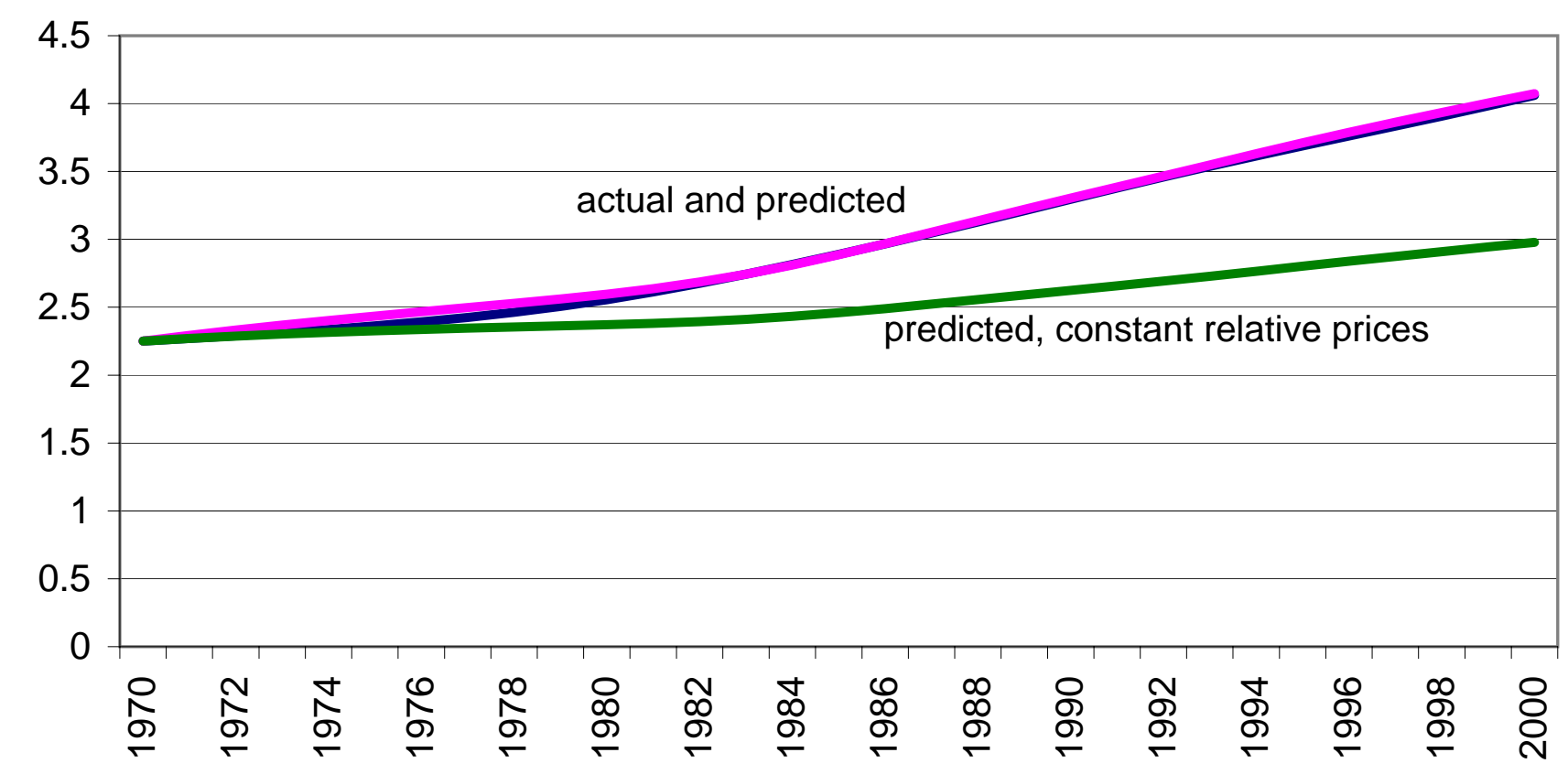

Figure 10 (b)

Predicted and actual hours of work, USA

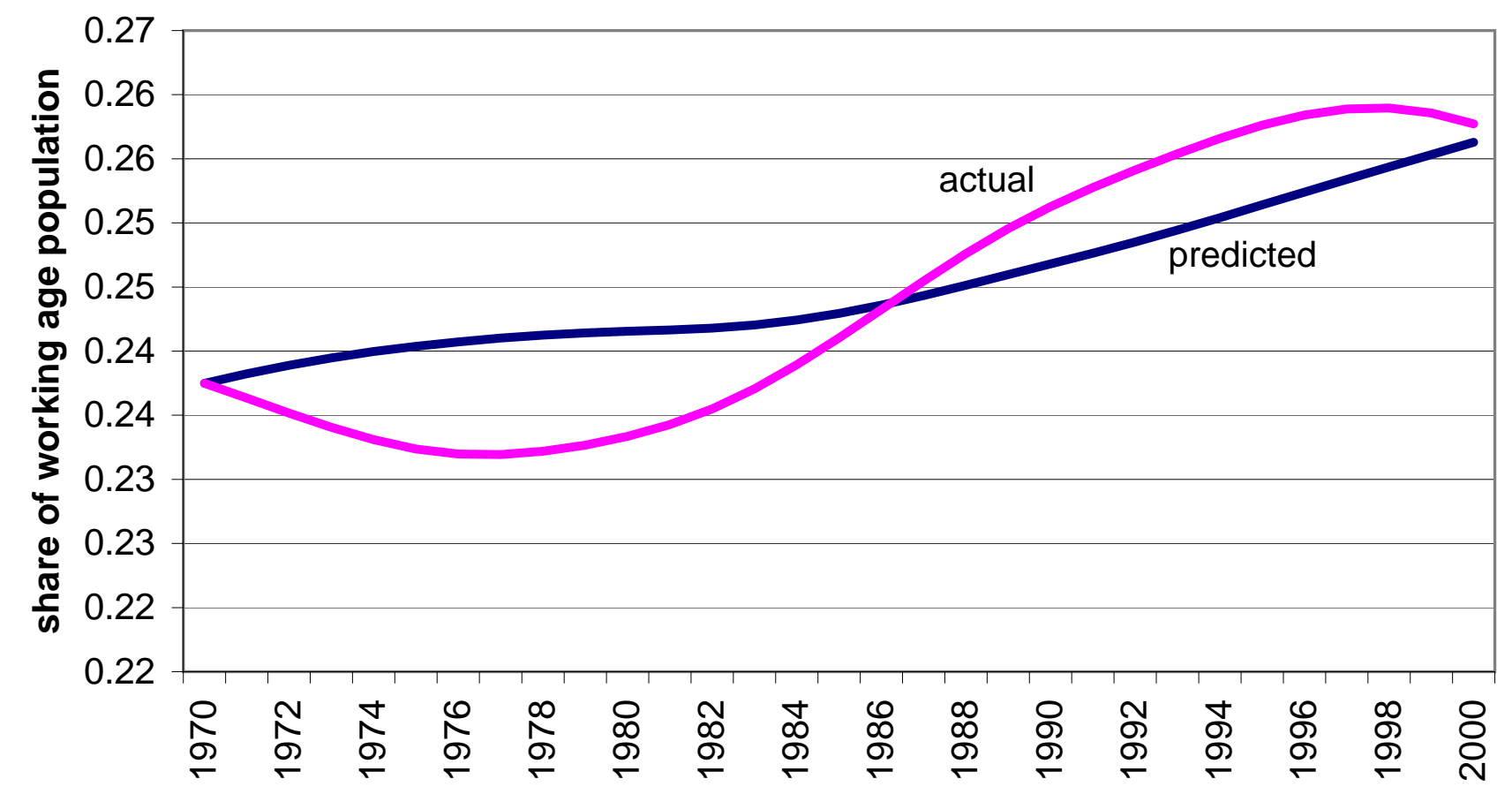


Figure 11

Predicted and actual service/nonservice employment Predicted and actual share of market time $=$ predicted = actual
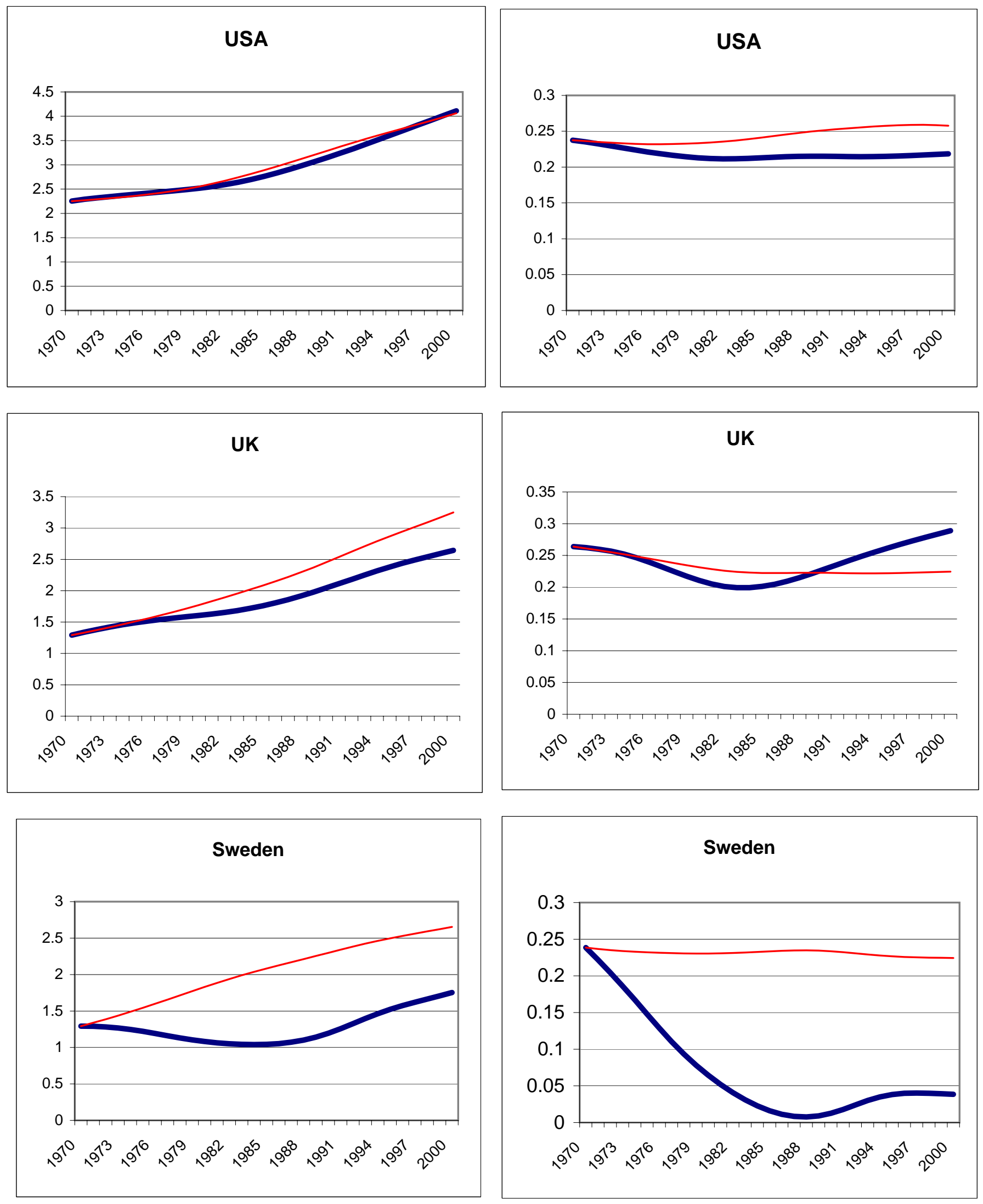
Figure 11, cont.

Predicted and actual service/nonservice employment

Predicted and actual share of market time $=$ predicted = actua
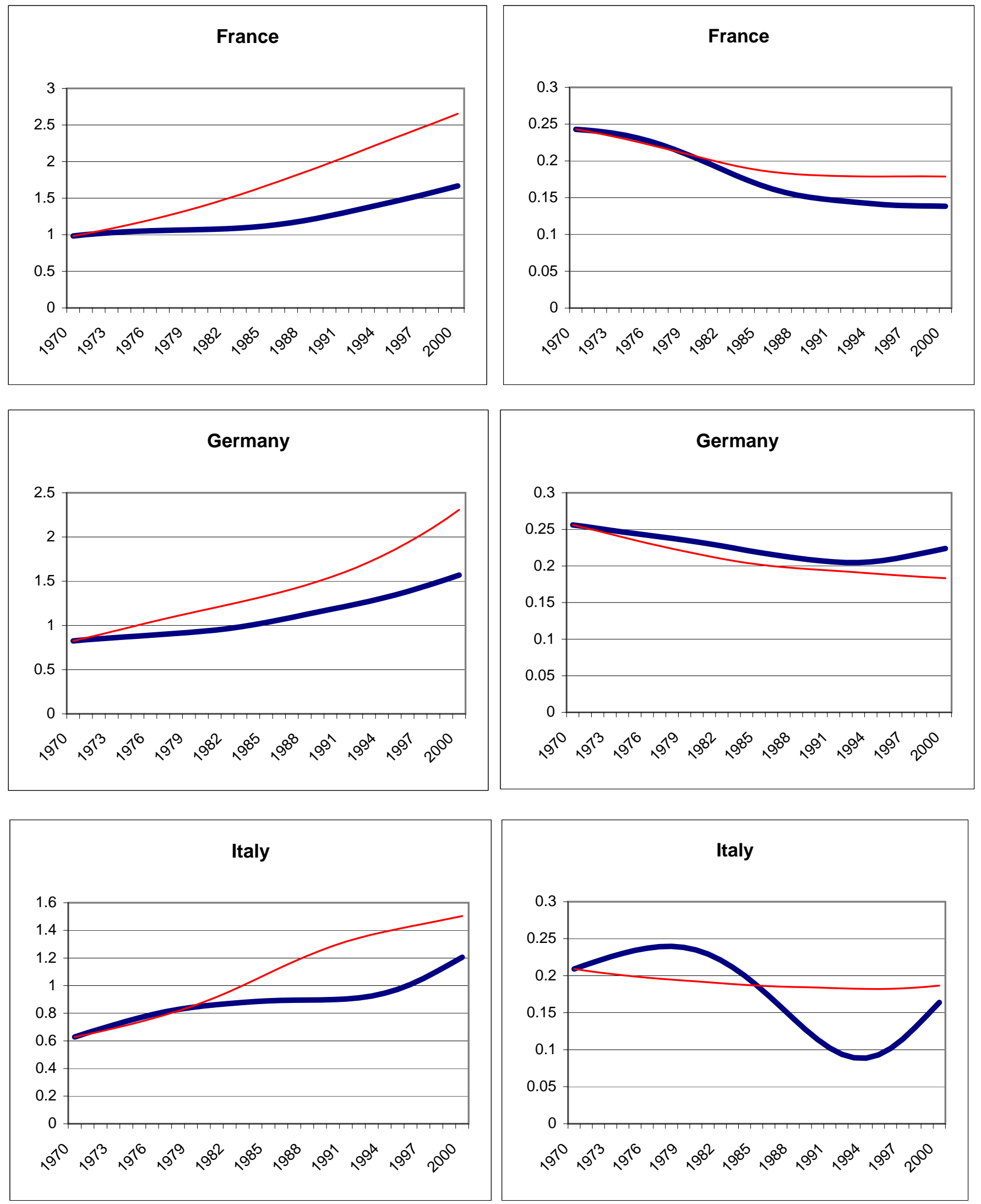


\section{Notes on figures}

\section{Figure 1}

GDP in international PPP dollars divided by hours of work.

Sources: Penn World Tables and Groningen Growth and Development Centre (see also Maddison, 1995)

\section{Figure 2}

ILO/OECD unemployment rate. EU3 is the average for France, Germany and Italy Source: Angus Maddison Dynamic Forces in Capitalist Development, Oxford: University Press, and OECD Employment Outlook

\section{Figure 3}

Sources: Groningen Growth and Development Centre

\section{Figure 4}

Proportion of employees in the service sector multiplied by total annual hours of work divided by population of working age

Sources: Groningen Growth and Development Centre and OECD STAN Database for Industrial Analysis

\section{Figure 5}

OECD unemployment rate versus labor force (employed and unemployed) divided by population of working age

Sources: OECD Employment Outlook

\section{Figures 7 and 8}

All data used in the unemployment prediction have already been defined in preceding graphs

\section{Figures 9 and 10}

Data used in the construction: Total market hours and service hours as before. Total hours of home production from Ramey and Francis (2005). Sectoral output obtained from STAN Database for Industrial Analysis by aggregating individual sectors after converting in international PPP dollars. Sectoral productivity is sectoral output divided by hours of work.

\section{Figure 11}

Taxes obtained from CEP/OECD data set and defined as the total "tax wedge", which is the sum of the employment tax rate, the direct tax rate and the indirect tax rate (source: Nickell, Nunziata and Ochel 2005). 


\section{CENTRE FOR ECONOMIC PERFORMANCE \\ Recent Discussion Papers}

756 Gilles Duranton

Henry Overman

755 Laura Alfaro

Andrew Charlton

754 Marco Manacorda

Alan Manning

Jonathan Wadsworth

753 Mariano Bosch

William Maloney

752 David Marsden

751 Peter Boone

Zhaoguo Zhan

750 Evangelia Vourvachaki

749 Mirko Draca

Raffaella Sadun

John Van Reenen

748 Gilles Duranton

Laurent Gobillon

Henry G. Overman

747 David Marsden

Richard Belfield

746 L Rachel Ngai

Christopher A. Pissarides

745 Michael White

Alex Bryson
Exploring the Detailed Location Patterns of UK Manufacturing Industries Using Microgeographic Data

International Financial Integration and Entrepreneurship

The Impact of Immigration on the Structure of Male Wages: Theory and Evidence from Britain.

Gross Worker Flows in the Presence of Informal Labour Markets. The Mexican Experience 1987-2002

Individual Employee Voice: Renegotiation and Performance Management in Public Services

Lowering Child Mortality in Poor Countries: The Power of Knowledgeable Parents

Information and Communication Technologies in a Multi-Sector Endogenous Growth Model

Productivity and ICT: A Review of the Evidence

Assessing the Effects of Local Taxation Using Microgeographic Data

Pay for Performance Where Output is Hard to Measure: the Case of Performance Pay for Teachers

Trends in Hours and Economic Growth

Unions, Job Reductions and Job Security Guarantees: the Experience of British Employees 
744 Wendy Carlin

Andrew Charlton

Colin Mayer

743 Carlos Thomas

742 Tobias Kretschmer Katrin Muehlfeld

741 Francesco Caselli

Nicola Gennaioli

740 Michael Noel Mark Schankerman

739 Nick Bloom Stephen Bond John Van Reenen

738 Sami Napari

737 Tobias Kretschmer

736 Andrew B. Bernard Stephen J. Redding Peter K. Schott

735 Francesco Caselli James Feyrer

734 Frédéric Robert-Nicoud

733 Alex Bryson Michael White
Capital Markets, Ownership and Distance

Equilibrium Unemployment and Optimal Monetary Policy

Co-Opetition and Prelaunch in Standard Setting for Developing Technologies

Dynastic Management

Strategic Patenting and Software Innovation

Uncertainty and Investment Dynamics

The Early Career Gender Wage Gap

Competing Technologies in the Database Management Systems Market

Multi-Product Firms and Product Switching

The Marginal Product of Capital

Off-Shoring of Business Services and DeIndustrialization: Threat or Opportunity - and for Whom?

Unions, Within-Workplace Job Cuts and Job Security Guarantees

The Centre for Economic Performance Publications Unit

Tel 02079557673 Fax 02079557595 Email info@cep.lse.ac.uk Web site http://cep.Ise.ac.uk 